\title{
Article \\ Analysis of TERT Isoforms across TCGA, GTEx and CCLE Datasets
}

\author{
Mathushan Subasri ${ }^{1}$, Parisa Shooshtari ${ }^{2,3,4,5}$, Andrew J. Watson $1,5,6$ and Dean H. Betts $1,5,6, *$ (D) \\ 1 Department of Physiology and Pharmacology, The University of Western Ontario, \\ London, ON N6A 5C1, Canada; msubasri@uwo.ca (M.S.); andrew.watson@schulich.uwo.ca (A.J.W.) \\ 2 Ontario Institute for Cancer Research, Toronto, ON M5G 0A3, Canada; pshoosh@uwo.ca \\ 3 Department of Pathology and Laboratory Medicine, The University of Western Ontario, \\ London, ON N6A 5C1, Canada \\ 4 Department of Computer Science, The University of Western Ontario, London, ON N6A 5C1, Canada \\ 5 The Children's Health Research Institute-Lawson Health Research Institute, London, ON N6C 2R5, Canada \\ 6 Department of Obstetrics and Gynaecology, The University of Western Ontario, \\ London, ON N6A 5C1, Canada \\ * Correspondence: dean.betts@schulich.uwo.ca; Tel.: +1-519-661-2111 (ext. 83786)
}

Citation: Subasri, M.; Shooshtari, P.; Watson, A.J.; Betts, D.H. Analysis of TERT Isoforms across TCGA, GTEx and CCLE Datasets. Cancers 2021, 13, 1853. https://doi.org/10.3390/

cancers13081853

Academic Editor: Izumi Horikawa

Received: 1 March 2021

Accepted: 8 April 2021

Published: 13 April 2021

Publisher's Note: MDPI stays neutral with regard to jurisdictional claims in published maps and institutional affiliations.

Copyright: (c) 2021 by the authors. Licensee MDPI, Basel, Switzerland. This article is an open access article distributed under the terms and conditions of the Creative Commons Attribution (CC BY) license (https:/ / creativecommons.org/licenses/by/ $4.0 /)$.
Simple Summary: All cancers must maintain telomere length to achieve immortality and around $80 \%$ do so by reactivating the enzyme complex telomerase. The diverse regulatory mechanisms surrounding the enzymatic component, telomerase reverse transcriptase (TERT), are often exploited during tumorigenesis to achieve reactivation. Since TERT isoform expression and regulation is heterogenous in nature, we assessed changes in TERT alternative splicing patterns between the normal and neoplastic states across tissue subtypes. We confirmed gene-level TERT overexpression, as well as splicing shifts away from enzymatically non-functional isoforms in neoplastic tissue. Analysis of tissue and cancer-subtype specific TERT expression patterns uncovered heterogenous expression, regulation, and the potential impact of variable telomere maintenance on tumorigenesis. To guide future studies, we clustered cancer cell lines with tumors from related origin based on TERT isoform expression patterns.

Abstract: Reactivation of the multi-subunit ribonucleoprotein telomerase is the primary telomere maintenance mechanism in cancer, but it is rate-limited by the enzymatic component, telomerase reverse transcriptase (TERT). While regulatory in nature, TERT alternative splice variant/isoform regulation and functions are not fully elucidated and are further complicated by their highly diverse expression and nature. Our primary objective was to characterize TERT isoform expression across 7887 neoplastic and 2099 normal tissue samples using The Cancer Genome Atlas (TCGA) and the Genotype-Tissue Expression Project (GTEx), respectively. We confirmed the global overexpression and splicing shift towards full-length TERT in neoplastic tissue. Stratifying by tissue type we found uncharacteristic TERT expression in normal brain tissue subtypes. Stratifying by tumorspecific subtypes, we detailed TERT expression differences potentially regulated by subtype-specific molecular characteristics. Focusing on $\beta$-deletion splicing regulation, we found the NOVA1 transacting factor to mediate alternative splicing in a cancer-dependent manner. Of relevance to future tissue-specific studies, we clustered cancer cell lines with tumors from related origin based on TERT isoform expression patterns. Taken together, our work has reinforced the need for tissue and tumourspecific TERT investigations, provided avenues to do so, and brought to light the current technical limitations of bioinformatic analyses of TERT isoform expression.

Keywords: telomere maintenance mechanism; telomerase reverse transcriptase; alternative splicing; Pan-Cancer 


\section{Introduction}

Somatic cells have limited replicative capacity, also called the "Hayflick limit", due to replication-mediated terminal DNA shortening [1]. During DNA replication, the leading strand is synthesized uninterruptedly from the $5^{\prime}$ terminus toward the $3^{\prime}$ unwinding replication fork. In contrast, the lagging strand is synthesized away from the replication fork in small $5^{\prime}$ to $3^{\prime}$ Okazaki fragments to satisfy the unidirectionality of DNA polymerases [2]. As a result, $\sim 50-100$ nucleotides are progressively lost during each cellular division from the $5^{\prime}$ end of the lagging daughter strand [3]. To prevent erosion of essential genomic sequences and activation of unwarranted DNA damage responses, human chromosomes are capped with 5-15 kilobases of tandemly repeated hexameric sequences (5'-TTAGGG$\left.3^{\prime}\right)$ [4]. Collectively, these repeats and their associated proteins form the nucleoprotein complex called telomeres [5,6]. While buffering the loss of integral DNA sequences, cellular division will irreversibly shorten telomeres, unless otherwise re-lengthened. The only proven telomere maintenance mechanisms (TMM) are telomerase-mediated lengthening or alternative lengthening of telomeres (ALT) [7]. Sustained replication-induced genomic degradation imposes a selective pressure permitting only the survival of cells acquiring one of these TMMs. Occurring in 1 out of $10^{6}-10^{8}$ cells [8], $\sim 85 \%$ of cancer cells (typically of epithelial origin) employ telomerase-mediated telomere maintenance while the remaining $\sim 10-15 \%$ (typically of mesenchymal or neuroepithelial origin) utilize ALT [9-11].

Telomerase, a unique reverse transcriptase (RT) ribonucleoprotein, is made of two core subunits: telomerase reverse transcriptase (TERT) and telomerase RNA component (TERC) $[12,13]$. The TERC subunit serves as a complementary internal template, while TERT possess catalytic activity and mediate the de novo synthesis of telomeric repeats [14]. Both TERT and TERC are sufficient and necessary for activity in vitro [15]. Additional accessory proteins such as the H/ACA protein complex (NHP2, NOP10, GAR1 and Dyskerin) are associated with telomerase activity (TA) and are required for various regulatory processes in vivo [16-18]. Both TA and telomere length (TL) are negatively associated with cellular developmental potency. While germ and stem cells exhibit TA, most terminally differentiated somatic cells have short TL and infrequent TA [12]. Some highly mitotic somatic cell types display appreciable levels of TA. For example, keratinocytes from the basal epidermal layer, late proliferative stage epithelial cells of the endometrium, and leukocytes [19-22]. Historically, somatic cells were presumed to have zero TERT expression due to poor PCR primer orientation within spliced regions [23]. Now it is clear somatic cells do express TERT, but they are predominantly alternative splice variants (ASV) [23].

Full-length (FL) TERT spanning 16 exons is the sole isoform retaining catalytic activity as most splice events perturb at least one of seven RT motifs in exons 4-11 [24]. Currently, 22 human TERT ASVs have been identified in vitro, comprised of various combinations of independent splicing events [23] (Figure 1). Since TERT is weakly expressed, alternative splicing is proposed to attenuate TA, but remains largely unelucidated compared to other transcriptional regulatory methods [25]. Complicating matters is the heterogenous expression patterns observed between and even within tumor types [24,26-28]. Tackling this issue, recent studies have utilized a Pan-Cancer bioinformatic approach towards telomere/telomerase research [29-31]. However, equivalently assessing matched normal tissue types and tumor-subtypes has not been conducted. By expanding the breadth and depth of inquisition, we may uncover novel conserved or specialized expression patterns that can be clinically exploited. Taken together, our work has elucidated some novel TERT expression patterns in normal and neoplastic tissue subtypes, potential mechanisms for these differences, avenues to explore them in vitro, and the major limitations of RNA-sequencing for the TERT gene and differential isoform expression. 


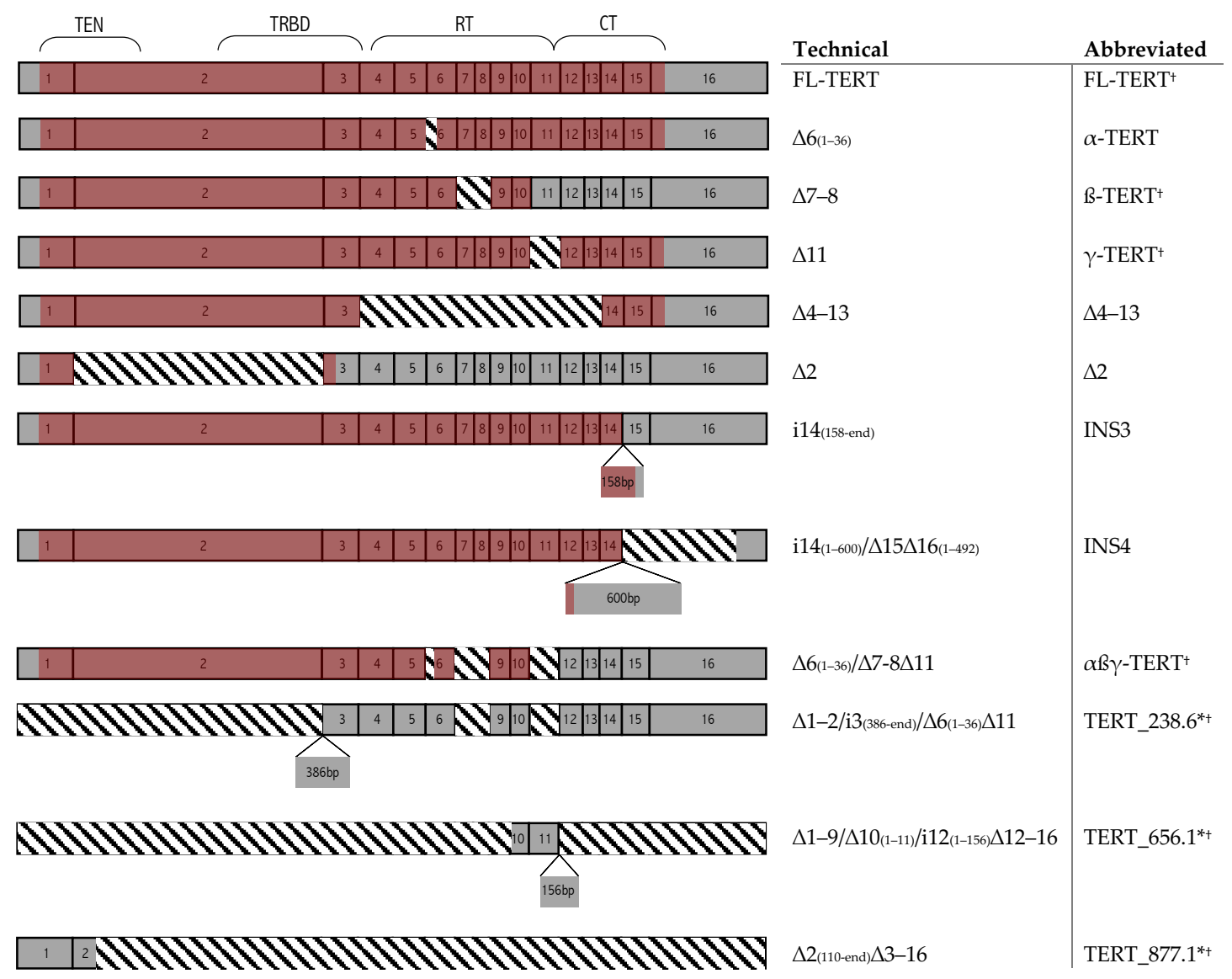

Figure 1. mRNA structure of commonly investigated TERT isoforms and those annotated in Ensembl Build 93. Fulllength (FL)TERT consists of 16 exons that make up four domains: TEN, TRBD, RT, and CT. Splicing can involve deletions, which are marked with downward diagonal stripes; or insertions, which are marked with smaller boxes indicating insertional size and an arrowhead indicating the insertional point. ORFs are shown with a light red shade layered over the mRNA structure. Technical isoform name terminology includes " $\Delta$ " representing deletions and " $i$ " representing insertions. * Abbreviated names are taken from Ensembl transcript ID (TERT_238.6—ENST00000484238.6; TERT_656.1— ENST00000503656.1; TERT_877.1_ENST00000522877.1). ${ }^{\dagger}$ Indicates transcripts annotated in Ensembl Build 93. All Ensembl transcripts are either automatically generated from the Ensembl genebuild pipeline or manually annotated by human and vertebrate analysis and annotation (HAVANA), supported by transcriptional evidence either from complementary DNA, expressed sequence tags, or protein sequences. Telomerase essential N-terminal domain (TEN); Telomerase RNA binding domain (TRBD); C-terminal extension domain (CT); Central catalytic reverse transcriptase domain (RT); Open-reading frame (ORF).

\section{Results}

\subsection{TERT Expression across Tumor and Normal Tissues}

Overall, TERT gene expression was low, with mean expression values less than one transcript per million (TPM) in every cancer type except thymic tumours (Figure 2). Among the 33 cancer types, eight had at least $25 \%$ of samples expressing zero TERT (Figure S1). Specifically, these TERT-negative cancer types were related to adrenal, kidney, thyroid, brain or soft tissue origin. In contrast, among the 19 normal tissues types, most (9/16) had at least $50 \%$ of samples expressing zero TERT (Figure S2). The seven remaining normal tissue types with majority TERT-positive samples were blood, brain, colon, esophageal, skin, stomach, and testicular tissues. While brain cortical samples were used as the normal reference for gliomas, the highest TERT expression among normal brain tissue subtypes, was in basal ganglia structures (Figure S3). 


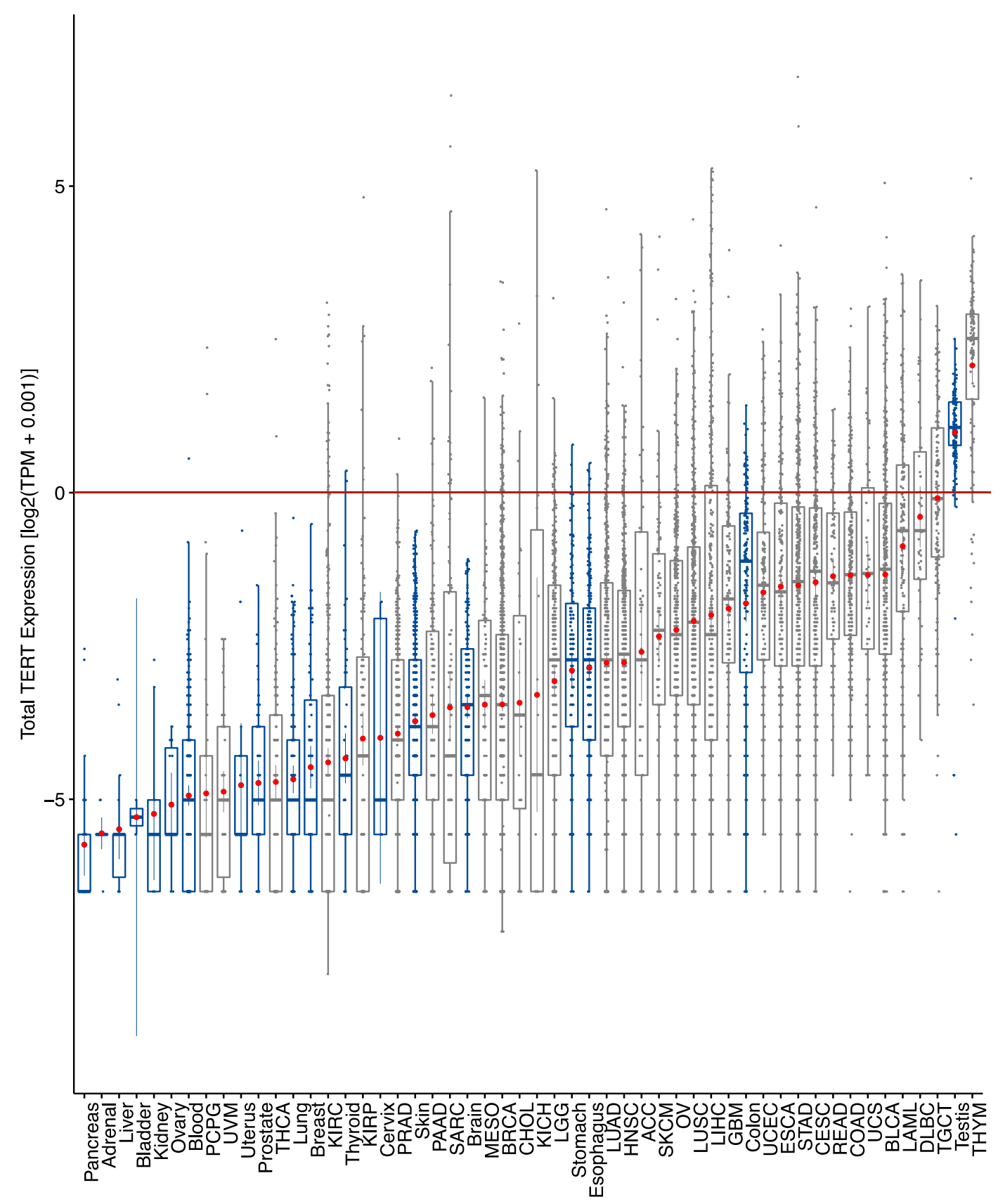

Figure 2. Variable total TERT expression observed across tumour and normal tissue types. Total TERT expression across TCGA tumours shows tumour-specific expression. Total TERT expression across GTEx normal tissue types shows the majority have low expression except for gastrointestinal and testicular tissue types. Box plots boxes denote the inter-quartile range as well as a bolded line representing the median. Extending from the boxes are minimum and maximum lines calculated from 1.5 times the interquartile range. Points outside this range are considered outliers. Within each box is a red point signifying the mean, as well as lines extending from this point representing a $95 \%$ confidence interval. Expression values in transcript per million (TPM) were transformed by a $\log _{2}(\mathrm{TPM}+0.001)$ equation. Horizontal line at $\mathrm{y}=0$ indicates 1 TPM.

\subsection{TERT Alternative Splice Variants}

Most (19/33) tumour types expressed all seven isoforms, 11/33 expressed six isoforms, and 3/33 expressed five isoforms (Figure S4). In contrast, some normal tissue types only expressed 2/7 isoforms (adrenal), 3/7 isoforms (liver) or 4/7 isoforms (ovary, pancreas) 
(Figure S5). Neoplastic samples primarily expressed FL-TERT, TERT_238.6, and TERT_656.1 (Figure S4). The primary isoform expressed across all normal tissue types was TERT_238.6, followed by FL-TERT in 11/16 tissue types. From the remaining 5/16, adrenal tissue and hepatic tissue did not express FL-TERT at all (Figure S5).

PCA biplots across cancer types, with some exceptions, showed that FL-TERT, TERT_238.6, and TERT_656.1 had strong positive correlations with each other (Figure S6). Albeit differences in expression relationships, normal tissue types with greater total TERT expression, such testicular tissue and the gastrointestinal tract tissues, more closely approximated what was observed in tumour tissues. However, there were still clear differences in the relationships between isoform expression between different tissue types and between the neoplastic and non-neoplastic states (Figure 3).
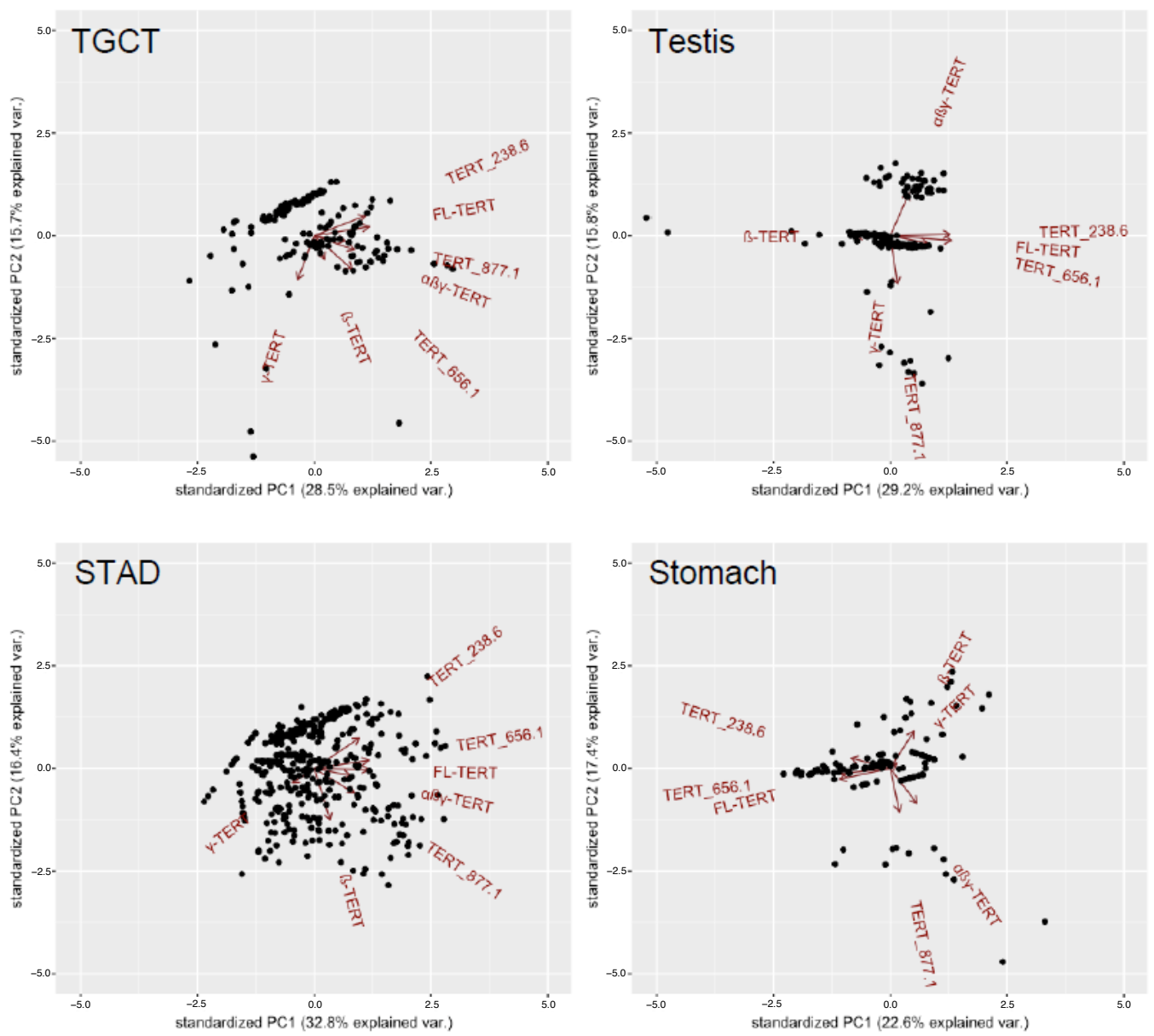

Figure 3. Expression relationships between TERT isoforms differ between tissue types and when in the neoplastic state. PCA biplots for testicular germ cell tumours (TGCT), stomach adenocarcinoma (STAD), and their respective matched normal tissues are shown as examples. Plotted using the first two principal components and show the loading vectors (arrows) of each TERT isoform variable expressed. The arrow length approximates the variance of the variable. The angle between arrows approximates the correlations between variables. Such that parallel arrows in the same direction have positive correlations, perpendicular arrows have no/weak correlations, and parallel arrows in the opposite direction have negative correlations.

Comparing telomerase activity gene signature expression to TERT_238.6 isoform percentage found significant negative correlations in 14/33 ( 42\%) cancer types (Figure 4), aligned with previous findings of TA inhibition by $\beta$-deleted TERT isoforms $[32,33]$. Finally, comparing TERT isoform expression with relative telomere length, a surprising significant negative correlation between FL-TERT expression in sarcomas was found (Figure 5). Interestingly, TGCT and THYM had significant positive correlations between telomere length 
and TERT_238.6 expression, but not with FL-TERT expression (Figure S7). Seeing as these cancer types had the highest total TERT expression and TERT_238.6 was the predominant isoform in most samples, this relationship may simply be reflecting one of total TERT expression and telomere re-lengthening. No other correlations between TERT isoform expression and relative telomere length were observed (Figures S7-S12).

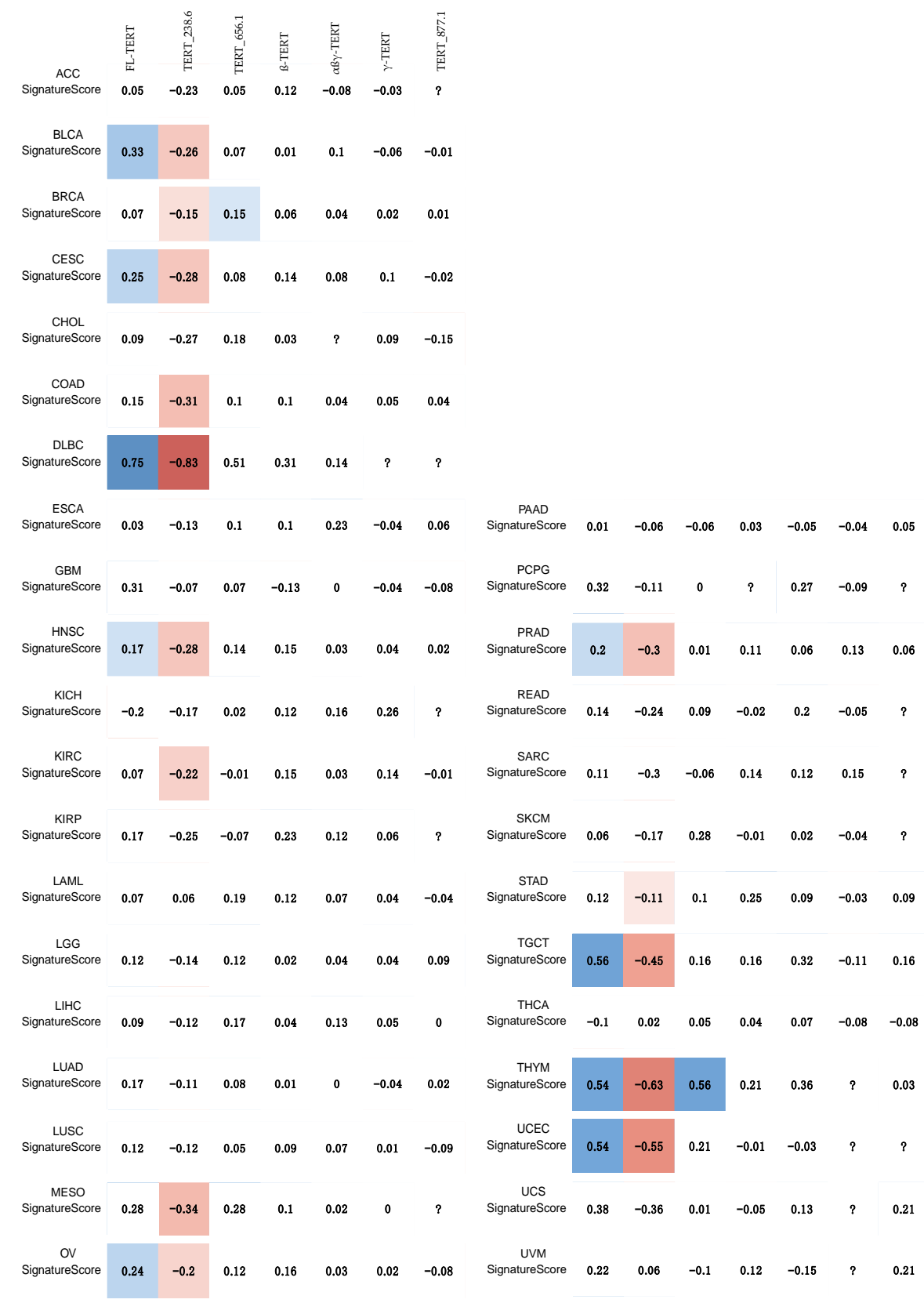

Figure 4. Telomerase activity signature score correlates to increased FL-TERT isoform percentage but decreased TERT_238.6 isoform percentage. FL-TERT isoform percentage (significant in 9/33 cancer types) had all positive correlations. TERT_238.6 isoform percentage had significant negative correlations in 14/33 cancer types and TERT_656.1 had significant positive correlations in $2 / 33$ cancer types. $\beta$-TERT, $\alpha \beta \gamma$-TERT, and $\gamma$-TERT isoform percentage had no significant correlations to signature score expression. Spearman correlations were computed and significance determined using a Bonferroni corrected $p$-value of $<0.000216$ ( $0.05 / 231$ comparisons). Correlations were highlighted with colour only if significant, blue indicating a significant positive correlation, and red indicating a significant negative correlation. Spearman's coefficients are displayed, and colour intensity also indicates the strength of correlation. Question marks ("?") indicate no correlation could be computed between signature score and the respective TERT isoform. 

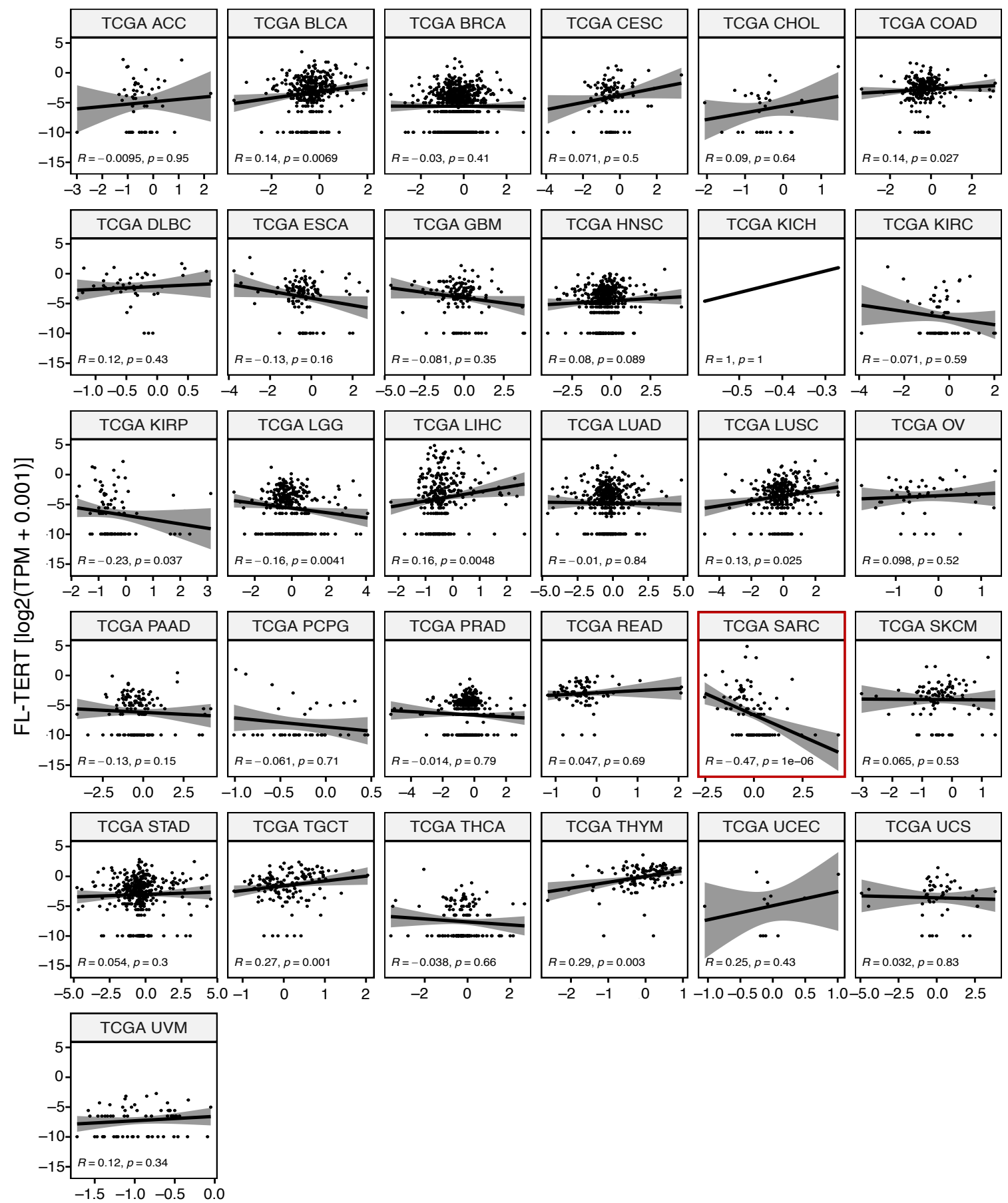

$\log ($ Tumour TL/Control TL)

Figure 5. FL-TERT isoform expression has a significant negative correlation only with telomere length ratio in sarcomas. Only SARC had significant correlation, which was negative. Telomere length ratios and FL-TERT expression were $\log _{10}$ and $\log _{2}(\mathrm{TPM}+0.001)$ transformed, respectively. Scatter plots were fitted with a linear regression line and $95 \%$ confidence interval. Spearman correlations were computed, and significance determined using a Bonferroni corrected $p$-value of $<0.000230(0.05 / 217$ comparisons). Significant correlations are highlighted with a red border.

\subsection{Tumor-Specific Subtype-Dependent Differences in TERT Isoforms}

To fully define TERT isoform expression heterogeneity, we evaluated the tumorspecific subtype-dependent differences. Several cancer types (14/29) presented at least one significant $(p<0.05)$ difference related to TERT expression or TL ratio. Cancer-specific molecular characterization papers of liver hepatocellular carcinoma (LIHC), lower grade 
glioma (LGG), and glioblastoma multiforme (GBM) have described mechanisms for their subtype-dependent differences in TERT expression [34,35]. For the remaining 11 cancer types, we postulated potential subtype-specific mechanisms by which TERT expression and TL are altered, and their resultant functions (Table 1). These mechanisms ranged from alterations of known TERT transcriptional influencers (i.e., NOTCH1, KRAS, FGFR3, ER), to heightened cellular potency, direct TERT alterations or larger genomic instabilities, TMM decision fate (i.e., telomerase-mediated or ALT), and confounding factors (i.e., immune cell infiltration).

Table 1. Significant tumor-specific subtype-dependent differences in TERT expression or telomere length.

\begin{tabular}{|c|c|c|c|c|}
\hline Tumour Type & Subtype & Category & Subtype Characterization ${ }^{1}$ & Potential Rationale $^{1}$ \\
\hline \multirow[b]{2}{*}{ BLCA } & Basal Squamous & $\uparrow$ FL-TERT & $\begin{array}{l}\text { High expression of stem-like } \\
\text { markers [36] }\end{array}$ & $\begin{array}{c}\text { Cellular potency is positively } \\
\text { associated with TERT } \\
\text { expression and TA activity } \\
{[37,38]}\end{array}$ \\
\hline & Neuronal & $\uparrow \alpha \beta \gamma$-TERT & $\begin{array}{c}\text { High frequency of RB1 } \\
\text { mutations, proliferative cell } \\
\text { state, increased expression } \\
\text { of neural and } \\
\text { neuroendocrine genes. } \\
\text { Worst survival outcome [36]. }\end{array}$ & N/A. \\
\hline BRCA & $\mathrm{C} 1$ & $\begin{array}{c}\downarrow \text { TERT } \\
\downarrow \text { TL Ratio }\end{array}$ & $\begin{array}{l}\text { Enriched for one or more } \\
\text { positive hormone receptors } \\
\text { and improved survival } \\
\text { outcome [39]. }\end{array}$ & $\begin{array}{l}\text { ER promotes TERT expression } \\
\text { by binding to TERT promoter } \\
\text { [40]. However, ER expression } \\
\text { is inversely correlated with } \\
\text { TERT expression [41]. Possible } \\
\text { negative feedback } \\
\text { control system. }\end{array}$ \\
\hline \multirow{2}{*}{ COAD/STAD } & CIN & $\uparrow \mathrm{TERT}$ & $\begin{array}{l}\text { Chromosomal } \\
\text { instability [42]. }\end{array}$ & $\begin{array}{l}\text { Aneuploidy is associated with } \\
\text { telomere deficiency [43-48] } \\
\text { but increased TERT expression } \\
\text { and TA [49]. } \\
\text { Aneuploidy-induced telomere } \\
\text { replication stress can be } \\
\text { alleviated by TA [50]. }\end{array}$ \\
\hline & GS & $\downarrow$ TERT & Genome stability [42]. & $\begin{array}{l}\text { Aneuploidy is associated with } \\
\text { telomere deficiency [43-48] } \\
\text { but increased TERT expression } \\
\text { and TA [49]. } \\
\text { Aneuploidy-induced telomere } \\
\text { replication stress can be } \\
\text { alleviated by TA [50]. }\end{array}$ \\
\hline HNSC & Basal & $\begin{array}{c}\downarrow \text { FL-TERT } \\
\downarrow \text { TERT } \\
\downarrow \text { TL Ratio }\end{array}$ & $\begin{array}{c}\text { Enriched NOTCH1 } \\
\text { inactivation, decreased } \\
\text { SOX2 expression and } \\
\text { HRAS-CASP8 } \\
\text { co-mutations [51]. }\end{array}$ & $\begin{array}{l}\text { NOTCH1 activation results in } \\
\text { increased TERT expression } \\
\text { and TA in dental follicle } \\
\text { cells [52]. }\end{array}$ \\
\hline LUAD & $\mathrm{C} 2$ & $\uparrow$ FL-TERT & $\begin{array}{l}\text { Exclusively PP tumors. } \\
\text { Enriched for KRAS } \\
\text { mutations and STK11 } \\
\text { inactivation [53]. }\end{array}$ & $\begin{array}{l}\text { KRAS mutation increases } \\
\text { TERT expression, TA and TL } \\
\text { in immortalized bronchial } \\
\text { epithelial and lung } \\
\text { adenocarcinoma cells [54]. }\end{array}$ \\
\hline LUSC & Primitive & $\uparrow$ FL-TERT Isoform \% & $\begin{array}{l}\text { Limited differentiating } \\
\text { qualities [55] }\end{array}$ & $\mathrm{N} / \mathrm{A}$ \\
\hline
\end{tabular}


Table 1. Cont.

\begin{tabular}{|c|c|c|c|c|}
\hline Tumour Type & Subtype & Category & Subtype Characterization ${ }^{1}$ & Potential Rationale $^{1}$ \\
\hline \multirow{3}{*}{ SARC } & $\mathrm{C} 1$ & $\downarrow$ TERT & $\begin{array}{l}\text { Primarily LMS tumors with } \\
\text { higher frequency of RB1 } \\
\text { mutations and no } \\
\text { association between TL and } \\
\text { ATRX alterations, unlike } \\
\text { UPS and MFS tumors [56]. }\end{array}$ & $\begin{array}{c}\text { UPS and MFS employ ALT via } \\
\text { ATRX alterations, but LMS } \\
\text { potentially does via loss of RB1 } \\
{[29,57]}\end{array}$ \\
\hline & $\mathrm{C} 2$ & $\uparrow \mathrm{TERT}$ & $\begin{array}{l}\text { Primarily DDLPS tumors. } \\
\text { Sub-cluster of DDLPS } \\
\text { tumors based on somatic } \\
\text { copy number alteration } \\
\text { found to have worse } \\
\text { survival and TERT } \\
\text { amplification [56]. }\end{array}$ & $\begin{array}{l}\text { TERT expression is } \\
\text { gene-dosage dependent [58]. } \\
\text { TERT amplification events are } \\
\text { rare but is associated with the } \\
\text { highest TA [29]. }\end{array}$ \\
\hline & $\mathrm{C} 4$ & $\uparrow \mathrm{TERT}$ & $\begin{array}{l}\text { Exclusively SS tumors. High } \\
\text { FGFR3, miR-183 expression } \\
\text { and PDE4A promoter } \\
\text { methylation [56]. }\end{array}$ & $\begin{array}{c}\text { FGFR3 gain-of-function } \\
\text { mutations and TERT promoter } \\
\text { mutations significantly } \\
\text { co-occur in bladder } \\
\text { cancer [59]. }\end{array}$ \\
\hline TGCT & Embryonal & $\uparrow \mathrm{TERT}$ & $\begin{array}{l}\text { NSE tumor subtype that } \\
\text { arises from early gonadal } \\
\text { stem cells and exhibits } \\
\text { gonadal morphology [60]. }\end{array}$ & $\begin{array}{l}\text { NSE tumors have increased } \\
\text { TERT expression, TL and } \\
\text { stemness gene expression [61]. } \\
\text { TERT expression and TA } \\
\text { decline with TCGT } \\
\text { differentiation status [62]. }\end{array}$ \\
\hline THYM & $\mathrm{C} 1, \mathrm{C} 3$ & $\uparrow \mathrm{TERT}$ & $\begin{array}{l}\text { Higher lymphocyte } \\
\text { content [63]. }\end{array}$ & $\begin{array}{c}\text { Normal lymphocytes have } \\
\text { endogenous TERT } \\
\text { expression [64]. }\end{array}$ \\
\hline
\end{tabular}

${ }^{1} \mathrm{TA}=$ telomerase activity; TL = telomere length; ATRX $=\alpha$-thalassaemia/mental retardation syndrome X-linked; DAXX $=$ death domainassociated protein; ALT = alternative lengthening of telomeres; RB1 = retinoblastoma protein; ER = estrogen receptor; GI = gastrointestinal; $\mathrm{PP}=$ proximal proliferative; LMS = smooth muscle differentiated leiomyosarcoma; UPS = undifferentiated pleomorphic sarcoma; MFS = myxofibrosarcoma; DDLPS = dedifferentiated liposarcoma; SS = synovial sarcoma; SE = seminoma; NSE = non-seminoma. $\uparrow$ TERT: increased TERT; $\downarrow$ TERT: decrease TERT.

\subsection{Cancer Cell Line TERT Isoform Expression Patterns}

In addition to heterogeneity in TERT expression patterns across and within tumor types, cancer cell lines are also reported to exhibit TERT isoform expression heterogeneity $[27,28]$. Suitable cell line selection is essential to accurately reflect the TERT transcriptome observed in primary tumors. We used Uniform Manifold Approximation and Projection (UMAP) to project average TERT isoform expression patterns in primary tumors with Cancer Cell Line Encyclopedia (CCLE) for 19 cell origin types (Figures S13-S30). The UMAP projection for breast carcinoma and related cancer cell lines is shown (Figure 6). Several cancer cell lines aligned closely with primary tumor TERT transcriptomes, while others did not (Table 2). While not all cell lines were profiled for TERT promoter mutational status [65], those with mutational status were annotated. Aligned with the TERT promoter mutation frequency that is observed in primary tumors [66], most lung cancer cell lines were wild-type (WT) while skin cancer lines frequently harbored promoter mutations. 


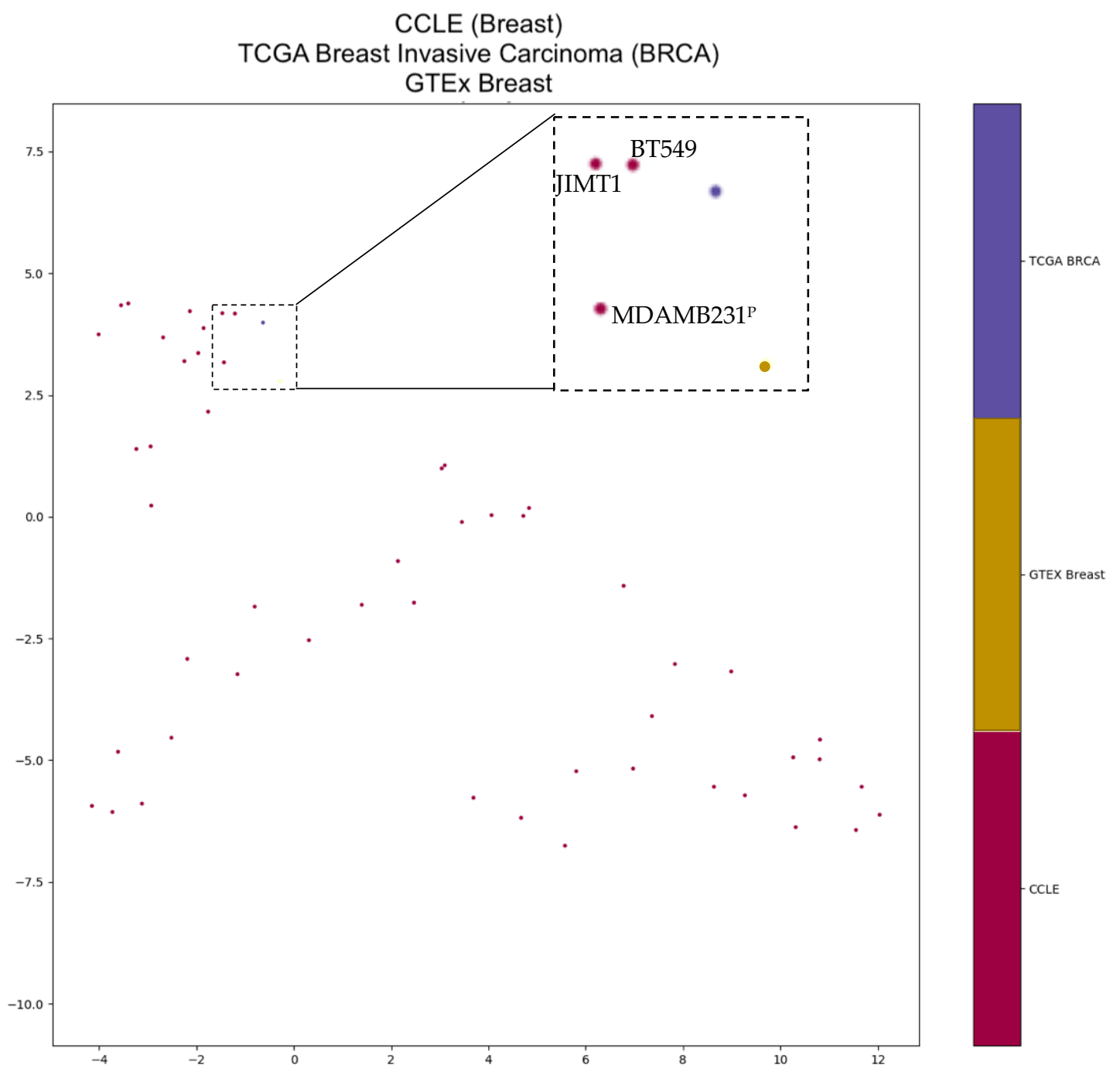

Figure 6. UMAP projection of breast CCLE cell lines, TCGA breast invasive carcinoma (BRCA), and GTEx breast using TERT isoform expression. Cell lines JIMT1 and BT549 were closest to average isoform percentage from TCGA BRCA. Cell line MDAMB231 was closest to average isoform percentage from GTEx breast. Cell line TERT promoter status taken from Ghandi et al., 2019. Superscript "P" indicates TERT promoter mutation, superscript "WT" indicates wild-type TERT promoter, and no superscript indicates no data available. Dashed-line box indicates a zoomed in region of interest with text labels of cell lines. UMAP Parameters: Manhattan distance, 8 Neighbours and 4 Components.

Table 2. Cancer cell lines clustered to related tumors based on TERT isoform expression patterns.

\begin{tabular}{|c|c|c|}
\hline Category & Tumor Type & Cancer Cell Line ${ }^{1}$ \\
\hline Biliary Tract & CHOL & $\mathrm{HUCCT}^{\dagger}, \mathrm{SNU} 89^{\dagger}$ \\
\hline \multirow{2}{*}{ Hematopoietic E Lymphoid Tissue } & LAML & OCIAML $^{+}$ \\
\hline & DLBC & SUPM2, KMH2, HL60, RS411, LOUCY \\
\hline \multirow{3}{*}{$\begin{array}{c}\text { Central Nervous System \& Autonomic } \\
\text { Ganglia }\end{array}$} & LGG & IOMMLEE, TM31 ${ }^{\dagger}$, LNZ308 \\
\hline & GBM & IOMMLEE, TM31, LNZ308 \\
\hline & PCPG & TM31, LNZ308, DKMG \\
\hline Breast & BRCA & JIMT1, BT549, MDAMB231 P \\
\hline \multirow[t]{2}{*}{ Large Intestine } & COAD & CL11 WT, SNU1197 WT, CW2 WT \\
\hline & CESC & JHUEM2, JHUEM7 \\
\hline \multirow[t]{2}{*}{ Endometrium } & UCEC & JHUEM2, JHUEM7 \\
\hline & UCS & JHUEM2, JHUEM7 \\
\hline Esophagus & ESCA & TE11 WT † , KYSE510, KYSE410 P , COLO680N \\
\hline
\end{tabular}


Table 2. Cont

\begin{tabular}{|c|c|c|}
\hline Category & Tumor Type & Cancer Cell Line $^{1}$ \\
\hline \multirow{3}{*}{ Kidney } & KIRC & CAKI1 WT \\
\hline & KIRP & CAKI1 WT \\
\hline & $\mathrm{KICH}$ & CAKI1 WT \\
\hline Liver & LIHC & HEPG $2^{\mathrm{P},+}$, LI7 \\
\hline \multirow{2}{*}{ Lung } & LUAD & NCIH2030 WT, DMS152, NCIH727 WT, MORCPR \\
\hline & LUSC & NCIH596 WT , NCIH2228 WT , NCIH1755 WT , CORL47 WT \\
\hline Ovary & $\mathrm{OV}$ & COV362 WT + , JHOM1, TOV112D, OVK18 WT \\
\hline Pancreas & PAAD & CAPAN1 $\mathrm{WT}+$ \\
\hline Pleura & MESO & NCIH2052 ${ }^{\mathrm{P}}$, ISTMES2 WT † \\
\hline Prostate & PRAD & PC $3^{\text {WT }}$ \\
\hline Skin & SKCM & SKMEL1, SKMEL28 ${ }^{\mathrm{P}}$, HT144 ${ }^{\mathrm{P}}$, HS695T $^{\mathrm{P}}$ \\
\hline \multirow{2}{*}{ Soft Tissue } & SARC & EW8, CADOES1 WT, RD \\
\hline & UCS & EW8, CADOES1 WT, RD \\
\hline Stomach & STAD & MKN7 WT, IM95 WT, OCUM1 \\
\hline Thyroid & THCA & TT2609C02 \\
\hline Urinary Tract & BLCA & UBLC1, UMUC2, CAL29 ${ }^{\dagger}, \mathrm{RT}_{4}{ }^{\dagger}$ \\
\hline
\end{tabular}

1 “WT" indicates wild-type TERT promoter status; "P" indicates mutated TERT promoter status; no superscript indicates TERT promoter status was not profiled [65]. ${ }^{\dagger}$ Indicates cell lines recommended by TCGA-110-CL [67].

\section{Discussion}

\section{1. $\beta$-Deletion General Prevalence but Cancer-Specific Regulation}

The necessity of telomere maintenance for neoplastic transformation has resulted in multiple studies characterizing TERT overexpression during tumorigenesis. Using the TCGA dataset, Barthel et al. observed TERT alterations in 95\% of TERT expressing samples and regardless of alteration type, all TERT altered groups displayed higher TERT expression than wild-type [29]. Similarly, we observed holistic TERT overexpression in tumor samples. At an isoform level, while tumor samples had higher TERT_238.6 expression, they typically had lower TERT_238.6 isoform percentage, indicating a shift in splicing away from FL-TERT. We also appreciated the strong negative correlation between TERT_238.6 isoform percentage and TA signature score expression-a finding that coincides with the negative inhibition that $\beta$-TERT confers on TA [32]. Seeing as the $\beta$-deletion, harbored by TERT_238.6, is most robustly expressed, recent efforts have uncovered regulatory features governing $\beta$-splicing. Using a TERT mini-gene construct containing exons $5-10$, three short intronic repeats essential for $\beta$-splicing were identified: intron 6 (B6 and DR6) and intron 8 (DR8) repeats [68]. Mechanistically, B6 undergoes RNA:RNA pairing with sequences in intron 8 to promote the $\beta$-deletion (removal of exons 7 and 8 ) by reducing the physical space between the splice sites at exon 6 and 9 [69]. Using varying combinations of these three cis-regulatory elements in mini-gene constructs and antisense oligonucleotides (ASO) to sterically hinder splice sites, B6 was considered necessary and sufficient for substantial $\beta$ deletion; DR6 potentiated $\beta$-deletion and DR8 were necessary for FL-TERT production [68]. However, a follow-up study using two lung cancer cell lines showed that DR8-mediated splicing control is cell-type specific, highlighting the complexity regarding TERT expression regulation [70]. With respect to trans-acting factors, the only experimentally supported factors to directly bind TERT pre-mRNA and direct splicing are NOVA Alternative Splicing Regulator 1 (NOVA1), Polypyrimidine-Tract Binding Protein 1 (PTBP1), and most recently RNA Binding Motif Protein 10 (RBM10) [70-72]. Firstly, using lung cancer cells, NOVA1 was shown to bind to a conserved motif in DR8 to promote FL-TERT splicing, TA, and telomere maintenance [70]. Moreover, PTPB1 was recruited by NOVA1 to DR8 motifs and also promote FL-TERT splicing, TA, and telomere maintenance [71]. Secondly, in pancreatic cancer, Xiao et al., used findings from the mini-gene constructs and mutation data from the TCGA dataset to identify and show that reduced RBM10 expression was significantly related to poorer survival [72]. Then, it was experimentally reported that RBM10 binds 
"GGU" motifs within the $5^{\prime}$ splice site of introns 7-8 of TERT pre-mRNA and promotes the exclusion of exons 7 and 8 to generate the $\beta$-deletion in pancreatic cell lines [72].

As such, we aimed to translate the NOVA1/PTBP1 findings to the TCGA RNAsequencing dataset. We grouped samples into FL-TERT expressing (isoform percentage $>0$ ) and non-expressing (isoform percentage $=0$ ) for all 33 cancer types. Comparing the expression of NOVA1 between these two groups, we only observed significantly higher NOVA1 expression in the FL-TERT-expressing group for only lung adenocarcinoma (LUAD), but significantly lower expression in the STAD and breast invasive carcinoma (BRCA) FL-TERT-expressing groups (Figure S31). In contrast, PTBP1 was significantly higher in the FL-TERT-expressing group for 10/33 cancer types (Figure S32). It is possible that PTBP1 is a ubiquitous regulator of FL-TERT splicing, working in concert with another tissue-specific trans-acting factor to direct DR8 bindings. This role is fulfilled in lung cancers by NOVA1, but the opposite seems to occur for other cancer types regarding NOVA1. This underscores the tissue and cell-type specific regulation of TERT expression and splicing.

\subsection{TMM Decision Fate}

Our tumor-subtype evaluations highlighted the various potential modalities of TERT expression changes. Notably for SARC, the smooth muscle differentiated leiomyosarcomas (LMS) subtype was characterized by low TERT expression, high RB1 mutation frequency, and no association between $\alpha$-thalassaemia/mental retardation syndrome X-linked (ATRX) mutations and telomere lengthening. ATRX and/or death domain-associated protein (DAXX) inactivation is commonly observed in ALT-positive tumors [73,74]. Together, they aid in the deposition of histone variant $\mathrm{H} 3.3$ into telomeres and while the resulting functions are unclear, ATRX/DAXX mutations are linked to telomere dysfunction [75]. Interestingly, a subset of tumors do not express TERT nor harbor ATRX/DAXX, but are enriched for retinoblastoma protein (RB1) mutations [29,57]. Therefore, the ALT phenotype may be activated through an independent pathway involving inactivation of RB1, but not ATRX/DAXX [57]. Whether decreased TERT expression is a consequence or cause for ALT fate determination is unclear. Furthermore, we investigated the relationship between TL and TERT isoforms and found SARC to have a significantly negative correlation between TL ratio and FL-TERT expression; a result previously observed in mesenchymal sarcomas [76]. Cancer cells are widely accepted to have shorter telomeres than matched normal tissue $[29,77]$, which are attributed to telomerase reactivation selection pressure once telomeres are critically short. Upon reactivation, subsequent re-lengthening may function in a maintenance capacity. However, ALT-predominated tumors like SARC have elongated telomeres, attributed to the ALT process involving homologous recombination [78]. Therefore, sarcomas likely undergo a determinative process for employing ALT-mediated telomere maintenance, resulting in longer telomeres or telomerase-mediated telomere maintenance resulting in shorter telomeres. Changes in TERT-related pathways, such as gene amplifications in dedifferentiated liposarcomas (DDLPS) or FGFR3 activation in synovial sarcomas (SS), likely promote telomerase-mediated telomere maintenance. Whereas, those in ALT-related pathways, such as RB1 in LMS sarcomas, likely promote ALT-mediated telomere maintenance. Interestingly, the classical hypothesis that TMM decision fate is absolute has been challenged with evidence of both mechanisms coexisting in cancer cells. This suggests that TMM fate can be dynamic and parallels the dynamics of epithelial-mesenchymal transitions $[77,79]$.

\subsection{Heterogenous and Specific TERT Transcriptomes}

Perturbed TERT gene expression, whether over-expressed, under-expressed or dysregulated, is associated with many disease processes. As such, TERT is regulated by various molecular modalities: pre-transcriptionally, post-transcriptionally, and post-translationally [25]. Our examination of TERT isoform expression patterns across tissue-types highlighted consensus FL-TERT and TERT_238.6 expression and splicing shifts during tumorigenesis. In 
addition, tissue-specific TERT transcriptomes were observed. Among normal brain tissue subtypes, basal ganglia structures had the highest TERT expression. TERT expression is important for neurodifferentiation and survival using rodent models [80]. While TA declines with brain development in humans [81], the expression and neuroprotection persists in adult rodent brain structures [82-84]. However, there are important species-dependent differences between human and rodent TERT. Notably, the rodent TERT promoter is significantly more active and rodent somatic tissues have elevated TA [85]. Nonetheless, TERT dysfunction may contribute to age-associated telomere shortening and neurodegenerative diseases involving the basal ganglia such as Parkinson's and Huntington's diseases $[82,86]$. While this paper focused on FL-TERT overexpression in the context of cancer, under-expression of FL-TERT and consequent telomere shortening is associated with telomeropathies including idiopathic pulmonary fibrosis, dyskeratosis congenita, and aplastic anemia [87]. While one potential molecular change that would result in reduced FL-TERT expression is splice site mutations, there are no direct relationships or functional consequences reported between increased TERT ASV expression and telomeropathy prevalence or disease severity.

In contrast, splicing dysregulation as a mechanism of FL-TERT overexpression has been associated with cancer promotion and progression [24]. Our work further reinforces the cell-type specific nature of TERT splicing dysregulation presented in the literature. For example, the $\beta$-deletion has been shown or speculated to be regulated by RMB10 in pancreatic cancer [72]; NOVA1/PTBP1 in lung cancer [70,71]; SRSF11, hnRNPH2, and hnRNPL in breast cancer [32]; and MCPH1/BRIT1 in ovarian cancer [88]. The malignant consequences of FL-TERT overexpression are two-fold. In the first instance, cellular immortalization is crucial for cancer cell survival and unattainable without sustained telomere maintenance [8-11]. In the second instance, TERT has many proposed non-canonical extra-telomeric roles, primarily by regulating gene expression as a transcriptional factor/cofactor [89]. Of note, TERT is involved in Wnt/ $\beta$-catenin $[90,91]$ and Nuclear Factor kappalight-chain-enhancer of activated B cells (NF- $\mathrm{kB}$ ) signaling [92]. These pathways control phenotypes exacerbated in cancer, namely cell survival, proliferation and migration. Recent evidence has also shown that ALT tumours may have decreased metastatic potential due to the lack of non-canonical functions [93]. This notion is reinforced by studies demonstrating the positive relationships between TERT and vascular endothelial growth factor (VEGF) [94], epithelial-to-mesenchymal transition [95], up-regulation of growth-promoting genes and down-regulation of pro-apoptotic genes [96], and mitochondrial resistance to stress $[97,98]$. While the nuances of these pathways have yet to be teased out, it is clear a flourishing environment is conferred through TERT overexpression.

Not as clear are the non-canonical extra-telomeric roles of TERT ASVs. To date, it has been shown that overexpression of $\beta$-TERT in breast cancer cells results in an anti-apoptotic chemoprotective phenotype [32], and overexpression of the $\Delta 4-13$ TERT variant in sarcoma cells induced proliferation via Wnt-signaling activation [23]. Therefore, it is plausible that some TERT ASVs retain the essential domains for similar non-canonical extra-telomeric consequences as FL-TERT but do so less efficiently-only presenting when artificially overexpressing beyond physiological abundances. Appreciating the existing limitations on functional research without TERT ASV-specific antibodies, it is still imperative to elucidate these possibly cancer-specific extra-telomeric functions so that therapeutic strategies to manipulate splicing away from FL-TERT can be developed, without realizing unintended adverse effects.

To aid future investigations and navigate the heterogeneity of TERT transcriptomes, we attempted to find suitable cancer cell lines for primary tumor types. While our clustering was based solely on TERT expression, other groups have done similar associations using the whole "omic" data [67,99]. Particularly, Yu et al. utilized the whole transcriptome to identify a comprehensive panel (TCGA-110-CL) of cell lines for 22 tumor types [67]. Interestingly, 9/21 cancer types (excluding SKCM because Yu et al. used metastatic samples) had at least one cell line recommended by both TCGA-110-CL and our TERT-based clustering [67]. 
This reinforces the use of the outlined cancer cell lines in these nine tumor types for TERT isoform research.

\subsection{Limitations}

While similar splice events to those in TERT_238.6, TERT_656.1, and TERT_877.1 have been observed [23], their complete transcripts have not been observed. TERT_238.6 has been cited only twice, and Slusher et al. referred to it simply as $\beta$-deleted TERT, despite also containing other splice events [31,100]. Using NCBI ORFFinder [101], the longest ORFs for TERT_238.6 spanned was 250 amino acids, in comparison to FL-TERT made of 1132 amino acids. Thus, TERT_238.6, if transcribed, likely undergoes non-sense mediated decay (NMD), unlike $\beta$-TERT, which undergoes NMD [102] but is also translated [32]. TERT_656.1 and TERT_877.1 are both composed of approximately two exons. Recently, Sayed et al. used targeted long-read length RNA sequencing and found $\Delta 5-15$ (deletions of exons 5 through 15) and $\Delta 4-15$ (deletions of exons 4 through 15) were among the most abundant TERT transcripts. While short TERT transcripts have been observed, there are potential avenues for sequencing-based misinterpretation.

Particularly, poly(A) RNA selection results in a 3' bias of selected RNA transcripts [103], the high $5^{\prime}$ guanine-cytosine content in exons 1 and 2 of TERT hinders accurate detection [104], and the scarcity of TERT expression requires large sequencing depth [105]. For these reasons, Barthel et al. opted to focus on sequencing and analysis of only exons $6-9$, limiting coverage solely to the $\beta$-deletion. Moving forward, these reservations must be kept in mind until sequencing biases are mitigated, and an accurate transcript annotation is used to reflect TERT isoforms observed in vitro. Using a combination of targeted RNA enrichment and direct long-read RNA-sequencing from the 3'-poly(A) tail to $5^{\prime}$ cap will allow for the most accurate identification and quantification of TERT isoforms [31,103].

Finally, the transcriptome annotations used for TCGA/GTEx and CCLE datasets were different, resulting in seven and eight annotated transcripts, respectively. However, the additional transcript used for CCLE was similar in RNA structure and identical in protein structure to $\beta$-TERT (Figure S11). Thus, reads were pooled with $\beta$-TERT for the CCLE dataset to match the TERT transcript annotation used for primary tumors. That is not to say the distribution of RNA sequencing reads would be congruent if the CCLE dataset was recomputed using a more recent TERT transcript annotation.

\section{Materials and Methods}

\subsection{Datasets}

We obtained TCGA $[106,107]$ and GTEx $[108,109]$ RNA sequencing expression data from the UCSC Toil RNA-seq recompute data hub ([110], accessed on 1 May 2020) at the UCSC Xena server [111,112]. Toil pipeline used the GRCh38 reference genome and Gencode v23 (Ensembl Build 93) transcript annotation. TCGA samples were filtered for only primary solid and primary blood derived tumors (Figure S33). While the TCGA project also excised and sequenced adjacent normal tissue samples from some cancer patients [113], these "normal" tissue samples may be affected by neighboring tumor cells [114-117], which is why GTEx samples were used for matched normal tissues. Samples having zero transcripts per million (TPM) for total TERT expression were removed (Figure S33). The total number of annotated transcripts for the Toil Recomputed dataset was 198,620; resulting in an average transcript relative abundance of $\sim 5$ TPM. Tumor subtype data was taken from landmark cancer-specific papers (Table S1). CCLE transcript expression and phenotypic characteristics were downloaded from the CCLE database ([118], accessed on 1 May 2020). CCLE [65] RNA-seq data was computed using the GRCh37 reference genome and Gencode v19 (Ensembl Build 75) transcript annotation. In this dated annotation, there is an additional TERT transcript (ENST00000296820.5; we abbreviated as TERT_820.5). RNA sequencing reads attributed to TERT_820.5 were pooled with $\beta$-TERT (TERT_104.2) due to their similar mRNA structure and identical protein structure (Figure S34). 


\subsection{Telomerase Activity Gene Signature Correlation Analysis}

Telomerase activity-related signature scores were calculated by summing a 43 gene set's TPM expression values (Table S2). Briefly, Barthel et al. performed differential gene expression analysis on Gene Expression Ominibus microarray data from four telomerase positive and four telomerase negative de-differentiated liposarcoma samples. This analysis resulted in 1302 genes that were enriched (fold-change $\geq 1.5$ ) in telomerase positive samples. After refinement, this list was reduced to 43 genes and validated, but did not reach significance in 11 urothelial cell carcinoma cell lines (Rho $=0.58, p=0.07$ ) [29]. Spearman's correlation was used to identify any relationships with TERT isoform percentages. Using 7 isoforms and 33 cancer types, significance was determined with a Bonferroni corrected $p$-value of $<0.000216(0.05 / 231$ comparisons $)$.

\subsection{Telomere Length Correlation Analysis}

Telomere length (TL) ratio values were taken from Barthel et al., where detailed methods can be found [29]. LAML and mesothelioma (MESO) did not have telomere length data. Briefly, TL was quantified using TelSeq [119] for both TCGA tumor samples and either matched normal tissue (NT) or matched normal blood (NB) leukocytes. Tumor TL was divided by matched normal TL to generate a TL ratio. The majority of normal samples were NB rather than NT, except for kidney samples. Comparing within tissues found NT samples had significantly longer telomere length estimates in bladder, liver, lung, and stomach tissue than NB samples (Figure S35). Therefore, TL ratios calculated using NT were excluded, with the exception of kidney samples because of the small sample size among NB calculated TL ratios. Spearman's correlation was used to identify any relationships with TERT isoform percentages. Using 7 isoforms and 31 cancer types, significance was determined with a Bonferroni corrected $p$-value of $<0.000230$ ( $0.05 / 217$ comparisons).

\subsection{Clustering Analysis}

Principal component analysis (PCA) was used for each cancer type and matched normal tissue to visualize the differences in isoform expression patterns. The variables included were the seven TERT transcripts' TPM expression values. The PCA plots were made using the first two principal components. Uniform Manifold Approximation and Projection (UMAP) was used for clustering [120] with CCLE samples. UMAP projections require input variables for number of neighbors, number of components, and the distance metric. The "Manhattan" distance was used, defined as the sum of the lengths of line segments in a rectangular grid between points. A python script iterated through neighbor values of $2,4,8,16,32,64$, and 128 , as well as component values of 2, 3, 4, 5, and 8 for each neighbor value to generate a maximum of 35 projections. A representative projection was chosen.

\section{Conclusions}

Sequencing costs have improved drastically over the last two decades, allowing for large scale projects such as TCGA, GTEx, and CCLE. With the plethora of "omic" data obtained, researchers have been empowered more than ever to elucidate the drivers of neoplastic transformation and progression, and provide clinically actionable guidance on diagnoses, prognoses, and therapeutic interventions. Herein, we initiate the characterization of the TERT transcriptome and outline possible research avenues in various normal and neoplastic tissue types. While descriptive in nature, our work emphasizes the cancer and cell-specific approach that future functional research should undertake. The next challenge will be integrating the multiple facets of TERT regulation and removing the ambiguity of isoform-level RNA sequencing while sustaining the large-scale feasibility necessary to uncover cell-type specific nuances and novel cancer therapeutic strategies. 
Supplementary Materials: The following are available online at https:/ /www.mdpi.com/article/ 10.3390 / cancers13081853/s1. Figure S1: Most TCGA tumour types have the majority of samples expressing TERT. Figure S2: Most GTEx normal tissue types have the majority of samples not expressing TERT. Figure S3: Total TERT expression is highest in basal ganglia brain structures in normal (GTEx) tissues. Figure S4: Cancers primarily express FL-TERT or TERT_238.6 followed by TERT_656.1. Figure S5: Normal tissues primarily express TERT_238.6 followed by different isoforms depending on tissue type. Figure S6: Normal tissue types with greater total TERT expression approximate the isoform correlation framework observed in tumour tissues. Figures S7-S12: TERT isoform's relationships to telomere length ratio across cancer types. Figure S13-S30: Tissue typespecific UMAP projections of TCGA, GTEx and CCLE samples. Figure S31: NOVA1 expression is significantly higher in the FL-TERT expressing group of only LUAD. Figure S32: PTBP1 expression is significantly higher in the FL-TERT expressing group of many cancer types. Figure S33: Data filtering workflow from the total TOIL recomputed dataset to only TERT-positive TCGA and matched GTEx samples, Figure S34: Ensembl annotations of TERT isoforms used in Toil recomputed dataset (Build 93) and CCLE dataset (Build 75). Figure S35: Comparison of telomere length from normal peripheral blood and normal adjacent tissue for each TCGA tissue type. Table S1: Selected subtypes for each TCGA cancer type identified through independent molecular profiling. Table S2: Telomerase activity score signature score gene list.

Author Contributions: Conceptualization, M.S., A.J.W., P.S. and D.H.B.; Data curation, M.S.; Formal analysis, M.S.; Funding acquisition, A.J.W. and D.H.B.; Investigation, M.S.; Methodology, M.S. and P.S.; Project administration, A.J.W. and D.H.B.; Resources, A.J.W. and D.H.B.; Software, M.S.; Supervision, A.J.W. and D.H.B.; Validation, M.S., A.J.W., P.S. and D.H.B.; Visualization, M.S.; Writingoriginal draft, M.S.; Writing-review \& editing, M.S., A.J.W., P.S. and D.H.B. All authors have read and agreed to the published version of the manuscript.

Funding: This research was funded by the Canadian Institutes of Health Research (CIHR) and graduate scholarships to Mathushan Subasri from the Natural Sciences and Engineering Research Council of Canada (NSERC) and The Children's Health Research Institute (CHRI).

Institutional Review Board Statement: Ethical review and approval were waived for this study because experimental animal or human studies were not performed, nor was the data used under controlled access.

Informed Consent Statement: All samples have been collected and utilized following strict human subject protection guidelines, informed consent and institutional review of protocols; TCGA [121] and GTEx [122].

Data Availability Statement: The data presented in this study are available from online databases or specific papers, as outlined in the methods section and Supplementary Materials (Table S1).

Acknowledgments: The results shown here are in part based upon RNA-sequencing data generated by the TCGA Research Network: http://cancergenome.nih.gov, accessed on 1 May 2020; The Genotype-Tissue Expression (GTEx) Consortium: https://gtexportal.org/home/, accessed on 1 May 2020; and The Broad Institute of MIT \& Harvard: https:/ / portals.broadinstitute.org/ccle, accessed on 1 May 2020.

Conflicts of Interest: The authors declare no conflict of interest.

\section{References}

1. Hayflick, L. The Limited In Vitro Lifetime of Human Diploid Cell Strains. Exp. Cell Res. 1965, 37, 614-636. [CrossRef]

2. Okazaki, R.; Okazaki, T.; Sakabe, K.; Sugimoto, K.; Sugino, A. Mechanism of DNA chain growth. I. Possible discontinuity and unusual secondary structure of newly synthesized chains. Proc. Natl. Acad. Sci. USA 1968, 59, 598-605. [CrossRef]

3. Harley, C.B.; Futcher, A.B.; Greider, C.W. Telomeres shorten during ageing of human fibroblasts. Nature 1990, 345, 458-460. [CrossRef] [PubMed]

4. Samassekou, O.; Gadji, M.; Drouin, R.; Yan, J. Sizing the ends: Normal length of human telomeres. Ann. Anat. 2010, 192, $284-291$. [CrossRef]

5. Olovnikov, A.M. A theory of marginotomy. The incomplete copying of template margin in enzymic synthesis of polynucleotides and biological significance of the phenomenon. J. Theor. Biol. 1973, 41, 181-190. [CrossRef]

6. Levy, M.Z.; Allsopp, R.C.; Futcher, A.B.; Greider, C.W.; Harley, C.B. Telomere end-replication problem and cell aging. J. Mol. Biol. 1992, 225, 951-960. [CrossRef] 
7. Dunham, M.A.; Neumann, A.A.; Fasching, C.L.; Reddel, R.R. Telomere maintenance by recombination in human cells. Nat. Genet. 2000, 26, 447-450. [CrossRef] [PubMed]

8. Castro-Vega, L.J.; Jouravleva, K.; Ortiz-Montero, P.; Liu, W.-Y.; Galeano, J.L.; Romero, M.; Popova, T.; Bacchetti, S.; Vernot, J.P.; Londoño-Vallejo, A. The senescent microenvironment promotes the emergence of heterogeneous cancer stem-like cells. Carcinogenesis 2015, 36, 1180-1192. [CrossRef] [PubMed]

9. Kim, N.W.; Piatyszek, M.A.; Prowse, K.R.; Harley, C.B.; West, M.D.; Ho, P.L.; Coviello, G.M.; Wright, W.E.; Weinrich, S.L.; Shay, J.W. Specific association of human telomerase activity with immortal cells and cancer. Science 1994, 266, 2011-2015. [CrossRef]

10. Shay, J.W.; Bacchetti, S. A survey of telomerase activity in human cancer. Eur. J. Cancer 1997, 33, 787-791. [CrossRef]

11. Heaphy, C.M.; Subhawong, A.P.; Hong, S.-M.; Goggins, M.G.; Montgomery, E.A.; Gabrielson, E.; Netto, G.J.; Epstein, J.I.; Lotan, T.L.; Westra, W.H.; et al. Prevalence of the alternative lengthening of telomeres telomere maintenance mechanism in human cancer subtypes. Am. J. Pathol. 2011, 179, 1608-1615. [CrossRef] [PubMed]

12. Greider, C.W. Telomeres, telomerase and senescence. Bioessays 1990, 12, 363-369. [CrossRef]

13. Blackburn, E.H. Structure and function of telomeres. Nature 1991, 350, 569-573. [CrossRef] [PubMed]

14. Wu, R.A.; Upton, H.E.; Vogan, J.M.; Collins, K. Telomerase Mechanism of Telomere Synthesis. Annu. Rev. Biochem. 2017, 86, 439-460. [CrossRef]

15. Weinrich, S.L.; Pruzan, R.; Ma, L.; Ouellette, M.; Tesmer, V.M.; Holt, S.E.; Bodnar, A.G.; Lichtsteiner, S.; Kim, N.W.; Trager, J.B.; et al. Reconstitution of human telomerase with the template RNA component hTR and the catalytic protein subunit hTRT. Nat. Genet. 1997, 17, 498-502. [CrossRef]

16. Mitchell, J.R.; Cheng, J.; Collins, K. A box H/ACA small nucleolar RNA-like domain at the human telomerase RNA 3' end. Mol. Cell. Biol. 1999, 19, 567-576. [CrossRef] [PubMed]

17. Pogacić, V.; Dragon, F.; Filipowicz, W. Human H/ACA small nucleolar RNPs and telomerase share evolutionarily conserved proteins NHP2 and NOP10. Mol. Cell. Biol. 2000, 20, 9028-9040. [CrossRef]

18. Cohen, S.B.; Graham, M.E.; Lovrecz, G.O.; Bache, N.; Robinson, P.J.; Reddel, R.R. Protein composition of catalytically active human telomerase from immortal cells. Science 2007, 315, 1850-1853. [CrossRef]

19. Härle-Bachor, C.; Boukamp, P. Telomerase activity in the regenerative basal layer of the epidermis inhuman skin and in immortal and carcinoma-derived skin keratinocytes. Proc. Natl. Acad. Sci. USA 1996, 93, 6476-6481. [CrossRef]

20. Kyo, S.; Takakura, M.; Kohama, T.; Inoue, M. Telomerase activity in human endometrium. Cancer Res. 1997, 57, 610-614.

21. Tanaka, M.; Kyo, S.; Takakura, M.; Kanaya, T.; Sagawa, T.; Yamashita, K.; Okada, Y.; Hiyama, E.; Inoue, M. Expression of telomerase activity in human endometrium is localized to epithelial glandular cells and regulated in a menstrual phase-dependent manner correlated with cell proliferation. Am. J. Pathol. 1998, 153, 1985-1991. [CrossRef]

22. Counter, C.M.; Gupta, J.; Harley, C.B.; Leber, B.; Bacchetti, S. Telomerase activity in normal leukocytes and in hematologic malignancies. Blood 1995, 85, 2315-2320. [CrossRef] [PubMed]

23. Hrdlicková, R.; Nehyba, J.; Bose, H.R.J. Alternatively spliced telomerase reverse transcriptase variants lacking telomerase activity stimulate cell proliferation. Mol. Cell. Biol. 2012, 32, 4283-4296. [CrossRef] [PubMed]

24. Liu, X.; Wang, Y.; Chang, G.; Wang, F.; Wang, F.; Geng, X. Alternative Splicing of hTERT Pre-mRNA: A Potential Strategy for the Regulation of Telomerase Activity. Int. J. Mol. Sci. 2017, 18, 567. [CrossRef] [PubMed]

25. Jie, M.-M.; Chang, X.; Zeng, S.; Liu, C.; Liao, G.-B.; Wu, Y.-R.; Liu, C.-H.; Hu, C.-J.; Yang, S.-M.; Li, X.-Z. Diverse regulatory manners of human telomerase reverse transcriptase. Cell Commun. Signal. 2019, 17, 63. [CrossRef]

26. Ludlow, A.T.; Robin, J.D.; Sayed, M.; Litterst, C.M.; Shelton, D.N.; Shay, J.W.; Wright, W.E. Quantitative telomerase enzyme activity determination using droplet digital PCR with single cell resolution. Nucleic Acids Res. 2014, 42, e104. [CrossRef] [PubMed]

27. Khosravi-Maharlooei, M.; Jaberipour, M.; Hosseini Tashnizi, A.; Attar, A.; Amirmoezi, F.; Habibagahi, M. Expression Pattern of Alternative Splicing Variants of Human Telomerase Reverse Transcriptase (hTERT) in Cancer Cell Lines Was not Associated with the Origin of the Cells. Int. J. Mol. Cell. Med. 2015, 4, 109-119.

28. Rowland, T.J.; Dumbović, G.; Hass, E.P.; Rinn, J.L.; Cech, T.R. Single-cell imaging reveals unexpected heterogeneity of telomerase reverse transcriptase expression across human cancer cell lines. Proc. Natl. Acad. Sci. USA 2019, 116, 18488-18497. [CrossRef]

29. Barthel, F.P.; Wei, W.; Tang, M.; Martinez-Ledesma, E.; Hu, X.; Amin, S.B.; Akdemir, K.C.; Seth, S.; Song, X.; Wang, Q.; et al. Systematic analysis of telomere length and somatic alterations in 31 cancer types. Nat. Genet. 2017, 49, 349-357. [CrossRef]

30. Luo, Z.; Wang, W.; Li, F.; Songyang, Z.; Feng, X.; Xin, C.; Dai, Z.; Xiong, Y. Pan-cancer analysis identifies telomerase-associated signatures and cancer subtypes. Mol. Cancer 2019, 18, 106. [CrossRef]

31. Slusher, A.L.; Kim, J.J.; Ludlow, A.T. The Role of Alternative RNA Splicing in the Regulation of hTERT, Telomerase, and Telomeres: Implications for Cancer Therapeutics. Cancers 2020, 12, 1514. [CrossRef]

32. Listerman, I.; Sun, J.; Gazzaniga, F.S.; Lukas, J.L.; Blackburn, E.H. The major reverse transcriptase-incompetent splice variant of the human telomerase protein inhibits telomerase activity but protects from apoptosis. Cancer Res. 2013, 73, 2817-2828. [CrossRef]

33. Akincilar, S.C.; Low, K.C.; Liu, C.Y.; Yan, T.D.; Oji, A.; Ikawa, M.; Li, S.; Tergaonkar, V. Quantitative assessment of telomerase components in cancer cell lines. FEBS Lett. 2015, 589, 974-984. [CrossRef] [PubMed]

34. TCGA Network Comprehensive and Integrative Genomic Characterization of Hepatocellular Carcinoma. Cell 2017, 169, 1327-1341.e23. [CrossRef] 
35. Ceccarelli, M.; Barthel, F.P.; Malta, T.M.; Sabedot, T.S.; Salama, S.R.; Murray, B.A.; Morozova, O.; Newton, Y.; Radenbaugh, A.; Pagnotta, S.M.; et al. Molecular Profiling Reveals Biologically Discrete Subsets and Pathways of Progression in Diffuse Glioma. Cell 2016, 164, 550-563. [CrossRef] [PubMed]

36. Robertson, A.G.; Kim, J.; Al-Ahmadie, H.; Bellmunt, J.; Guo, G.; Cherniack, A.D.; Hinoue, T.; Laird, P.W.; Hoadley, K.A.; Akbani, R.; et al. Comprehensive Molecular Characterization of Muscle-Invasive Bladder Cancer. Cell 2017, 171, 540-556.e25. [CrossRef] [PubMed]

37. Wright, W.E.; Piatyszek, M.A.; Rainey, W.E.; Byrd, W.; Shay, J.W. Telomerase activity in human germline and embryonic tissues and cells. Dev. Genet. 1996, 18, 173-179. [CrossRef]

38. Teichroeb, J.H.; Kim, J.; Betts, D.H. The role of telomeres and telomerase reverse transcriptase isoforms in pluripotency induction and maintenance. RNA Biol. 2016, 13, 707-719. [CrossRef]

39. Berger, A.C.; Korkut, A.; Kanchi, R.S.; Hegde, A.M.; Lenoir, W.; Liu, W.; Liu, Y.; Fan, H.; Shen, H.; Ravikumar, V.; et al. A Comprehensive Pan-Cancer Molecular Study of Gynecologic and Breast Cancers. Cancer Cell 2018, 33, 690-705.e9. [CrossRef]

40. Ramlee, M.K.; Wang, J.; Toh, W.X.; Li, S. Transcription Regulation of the Human Telomerase Reverse Transcriptase (hTERT) Gene. Genes 2016, 7, 50. [CrossRef] [PubMed]

41. Long, N.; Liu, N.; Liu, X.L.; Li, J.; Cai, B.Y.; Cai, X. Endometrial expression of telomerase, progesterone, and estrogen receptors during the implantation window in patients with recurrent implantation failure. Genet. Mol. Res. 2016, 15. [CrossRef]

42. Liu, Y.; Sethi, N.S.; Hinoue, T.; Schneider, B.G.; Cherniack, A.D.; Sanchez-Vega, F.; Seoane, J.A.; Farshidfar, F.; Bowlby, R.; Islam, M.; et al. Comparative Molecular Analysis of Gastrointestinal Adenocarcinomas. Cancer Cell 2018, 33, 721-735.e8. [CrossRef]

43. Blasco, M.A.; Lee, H.W.; Hande, M.P.; Samper, E.; Lansdorp, P.M.; DePinho, R.A.; Greider, C.W. Telomere shortening and tumor formation by mouse cells lacking telomerase RNA. Cell 1997, 91, 25-34. [CrossRef]

44. Lee, H.W.; Blasco, M.A.; Gottlieb, G.J.; Horner, J.W., 2nd; Greider, C.W.; DePinho, R.A. Essential role of mouse telomerase in highly proliferative organs. Nature 1998, 392, 569-574. [CrossRef] [PubMed]

45. Niida, H.; Matsumoto, T.; Satoh, H.; Shiwa, M.; Tokutake, Y.; Furuichi, Y.; Shinkai, Y. Severe growth defect in mouse cells lacking the telomerase RNA component. Nat. Genet. 1998, 19, 203-206. [CrossRef] [PubMed]

46. Plentz, R.R.; Schlegelberger, B.; Flemming, P.; Gebel, M.; Kreipe, H.; Manns, M.P.; Rudolph, K.L.; Wilkens, L. Telomere shortening correlates with increasing aneuploidy of chromosome 8 in human hepatocellular carcinoma. Hepatology 2005, 42, 522-526. [CrossRef]

47. Treff, N.R.; Su, J.; Taylor, D.; Scott, R.T.J. Telomere DNA deficiency is associated with development of human embryonic aneuploidy. PLoS Genet. 2011, 7, e1002161. [CrossRef] [PubMed]

48. Suraweera, N.; Mouradov, D.; Li, S.; Jorissen, R.N.; Hampson, D.; Ghosh, A.; Sengupta, N.; Thaha, M.; Ahmed, S.; Kirwan, M.; et al. Relative telomere lengths in tumor and normal mucosa are related to disease progression and chromosome instability profiles in colorectal cancer. Oncotarget 2016, 7, 36474-36488. [CrossRef] [PubMed]

49. Fang, X.; Hu, T.; Yin, H.; Yang, J.; Tang, W.; Hu, S.; Xu, X. Differences in telomerase activity and the effects of AZT in aneuploid and euploid cells in colon cancer. Int. J. Oncol. 2017, 51, 525-532. [CrossRef]

50. Meena, J.K.; Cerutti, A.; Beichler, C.; Morita, Y.; Bruhn, C.; Kumar, M.; Kraus, J.M.; Speicher, M.R.; Wang, Z.-Q.; Kestler, H.A.; et al. Telomerase abrogates aneuploidy-induced telomere replication stress, senescence and cell depletion. EMBO J. 2015, 34, 1371-1384. [CrossRef] [PubMed]

51. TCGA Network. Comprehensive genomic characterization of head and neck squamous cell carcinomas. Nature 2015, 517, 576-582. [CrossRef]

52. Chen, X.; Zhang, T.; Shi, J.; Xu, P.; Gu, Z.; Sandham, A.; Yang, L.; Ye, Q. Notch1 signaling regulates the proliferation and self-renewal of human dental follicle cells by modulating the G1/S phase transition and telomerase activity. PLoS ONE 2013, 8, e69967. [CrossRef]

53. TCGA Network. Comprehensive molecular profiling of lung adenocarcinoma. Nature 2014, 511, 543-550. [CrossRef] [PubMed]

54. Liu, W.; Yin, Y.; Wang, J.; Shi, B.; Zhang, L.; Qian, D.; Li, C.; Zhang, H.; Wang, S.; Zhu, J.; et al. Kras mutations increase telomerase activity and targeting telomerase is a promising therapeutic strategy for Kras-mutant NSCLC. Oncotarget 2017, 8, 179-190. [CrossRef] [PubMed]

55. TCGA Network. Comprehensive genomic characterization of squamous cell lung cancers. Nature 2012, 489, 519-525. [CrossRef]

56. TCGA Network Comprehensive and Integrated Genomic Characterization of Adult Soft Tissue Sarcomas. Cell 2017, 171, 950965.e28. [CrossRef] [PubMed]

57. ICGC/TCGA. Pan-Cancer Analysis of Whole Genomes Consortium Pan-cancer analysis of whole genomes. Nature 2020, 578, 82-93. [CrossRef]

58. Zhang, A.; Zheng, C.; Hou, M.; Lindvall, C.; Li, K.-J.; Erlandsson, F.; Björkholm, M.; Gruber, A.; Blennow, E.; Xu, D. Deletion of the telomerase reverse transcriptase gene and haploinsufficiency of telomere maintenance in Cri du chat syndrome. Am. J. Hum. Genet. 2003, 72, 940-948. [CrossRef]

59. Hosen, I.; Rachakonda, P.S.; Heidenreich, B.; de Verdier, P.J.; Ryk, C.; Steineck, G.; Hemminki, K.; Kumar, R. Mutations in TERT promoter and FGFR3 and telomere length in bladder cancer. Int. J. Cancer 2015, 137, 1621-1629. [CrossRef] [PubMed]

60. Shen, H.; Shih, J.; Hollern, D.P.; Wang, L.; Bowlby, R.; Tickoo, S.K.; Thorsson, V.; Mungall, A.J.; Newton, Y.; Hegde, A.M.; et al. Integrated Molecular Characterization of Testicular Germ Cell Tumors. Cell Rep. 2018, 23, 3392-3406. [CrossRef] 
61. Sun, H.; Kim, P.; Jia, P.; Park, A.K.; Liang, H.; Zhao, Z. Distinct telomere length and molecular signatures in seminoma and non-seminoma of testicular germ cell tumor. Brief. Bioinform. 2019, 20, 1502-1512. [CrossRef] [PubMed]

62. Schrader, M.; Burger, A.M.; Müller, M.; Krause, H.; Straub, B.; Schostak, M.; Schulze, W.; Lauke, H.; Miller, K. The differentiation status of primary gonadal germ cell tumors correlates inversely with telomerase activity and the expression level of the gene encoding the catalytic subunit of telomerase. BMC Cancer 2002, 2, 32. [CrossRef] [PubMed]

63. Radovich, M.; Pickering, C.R.; Felau, I.; Ha, G.; Zhang, H.; Jo, H.; Hoadley, K.A.; Anur, P.; Zhang, J.; McLellan, M.; et al. The Integrated Genomic Landscape of Thymic Epithelial Tumors. Cancer Cell 2018, 33, 244-258.e10. [CrossRef] [PubMed]

64. Hiyama, E.; Hiyama, K.; Yokoyama, T.; Shay, J.W. Immunohistochemical detection of telomerase (hTERT) protein in human cancer tissues and a subset of cells in normal tissues. Neoplasia 2001, 3, 17-26. [CrossRef] [PubMed]

65. Ghandi, M.; Huang, F.W.; Jané-Valbuena, J.; Kryukov, G.V.; Lo, C.C.; McDonald, E.R., 3rd; Barretina, J.; Gelfand, E.T.; Bielski, C.M.; Li, H.; et al. Next-generation characterization of the Cancer Cell Line Encyclopedia. Nature 2019, 569, 503-508. [CrossRef]

66. Liu, T.; Yuan, X.; Xu, D. Cancer-Specific Telomerase Reverse Transcriptase (TERT) Promoter Mutations: Biological and Clinical Implications. Genes 2016, 7, 38. [CrossRef]

67. Yu, K.; Chen, B.; Aran, D.; Charalel, J.; Yau, C.; Wolf, D.M.; van 't Veer, L.J.; Butte, A.J.; Goldstein, T.; Sirota, M. Comprehensive transcriptomic analysis of cell lines as models of primary tumors across 22 tumor types. Nat. Commun. 2019, 10, 3574. [CrossRef] [PubMed]

68. Wong, M.S.; Chen, L.; Foster, C.; Kainthla, R.; Shay, J.W.; Wright, W.E. Regulation of telomerase alternative splicing: A target for chemotherapy. Cell Rep. 2013, 3, 1028-1035. [CrossRef]

69. Wong, M.S.; Shay, J.W.; Wright, W.E. Regulation of human telomerase splicing by RNA:RNA pairing. Nat. Commun. 2014, 5, 3306. [CrossRef]

70. Ludlow, A.T.; Wong, M.S.; Robin, J.D.; Batten, K.; Yuan, L.; Lai, T.-P.; Dahlson, N.; Zhang, L.; Mender, I.; Tedone, E.; et al. NOVA1 regulates hTERT splicing and cell growth in non-small cell lung cancer. Nat. Commun. 2018, 9, 3112. [CrossRef]

71. Sayed, M.E.; Yuan, L.; Robin, J.D.; Tedone, E.; Batten, K.; Dahlson, N.; Wright, W.E.; Shay, J.W.; Ludlow, A.T. NOVA1 directs PTBP1 to hTERT pre-mRNA and promotes telomerase activity in cancer cells. Oncogene 2019, 38, 2937-2952. [CrossRef] [PubMed]

72. Xiao, W.; Chen, X.; Li, X.; Deng, K.; Liu, H.; Ma, J.; Wang, Z.; Hu, Y.; Hou, J. RBM10 regulates human TERT gene splicing and inhibits pancreatic cancer progression. Am. J. Cancer Res. 2021, 11, 157-170.

73. Heaphy, C.M.; de Wilde, R.F.; Jiao, Y.; Klein, A.P.; Edil, B.H.; Shi, C.; Bettegowda, C.; Rodriguez, F.J.; Eberhart, C.G.; Hebbar, S.; et al. Altered telomeres in tumors with ATRX and DAXX mutations. Science 2011, 333, 425. [CrossRef] [PubMed]

74. Ramamoorthy, M.; Smith, S. Loss of ATRX Suppresses Resolution of Telomere Cohesion to Control Recombination in ALT Cancer Cells. Cancer Cell 2015, 28, 357-369. [CrossRef] [PubMed]

75. Dyer, M.A.; Qadeer, Z.A.; Valle-Garcia, D.; Bernstein, E. ATRX and DAXX: Mechanisms and Mutations. Cold Spring Harb. Perspect. Med. 2017, 7, a026567. [CrossRef]

76. Chi, Y.; Shen, Q.; Wang, J.; Zheng, X.; Hou, L.; Zhang, B. Correlation of telomere length and the expression of its regulating proteins in mesenchymal sarcomas. Beijing Da Xue Xue Bao 2008, 40, 363-368. [PubMed]

77. Sung, J.-Y.; Lim, H.-W.; Joung, J.-G.; Park, W.-Y. Pan-Cancer Analysis of Alternative Lengthening of Telomere Activity. Cancers 2020, 12, 2207. [CrossRef]

78. Sieverling, L.; Hong, C.; Koser, S.D.; Ginsbach, P.; Kleinheinz, K.; Hutter, B.; Braun, D.M.; Cortés-Ciriano, I.; Xi, R.; Kabbe, R.; et al Genomic footprints of activated telomere maintenance mechanisms in cancer. Nat. Commun. 2020, 11, 733. [CrossRef] [PubMed]

79. Gocha, A.R.S.; Nuovo, G.; Iwenofu, O.H.; Groden, J. Human sarcomas are mosaic for telomerase-dependent and telomeraseindependent telomere maintenance mechanisms: Implications for telomere-based therapies. Am. J. Pathol. 2013, 182, 41-48. [CrossRef] [PubMed]

80. Mattson, M.P.; Fu, W.; Zhang, P. Emerging roles for telomerase in regulating cell differentiation and survival: A neuroscientist's perspective. Mech. Ageing Dev. 2001, 122, 659-671. [CrossRef]

81. Ulaner, G.A.; Hu, J.F.; Vu, T.H.; Giudice, L.C.; Hoffman, A.R. Telomerase activity in human development is regulated by human telomerase reverse transcriptase (hTERT) transcription and by alternate splicing of hTERT transcripts. Cancer Res. 1998, $58,4168-4172$.

82. Liu, M.-Y.; Nemes, A.; Zhou, Q.-G. The Emerging Roles for Telomerase in the Central Nervous System. Front. Mol. Neurosci. 2018, 11, 160. [CrossRef] [PubMed]

83. Lee, J.; Jo, Y.S.; Sung, Y.H.; Hwang, I.K.; Kim, H.; Kim, S.-Y.; Yi, S.S.; Choi, J.-S.; Sun, W.; Seong, J.K.; et al. Telomerase deficiency affects normal brain functions in mice. Neurochem. Res. 2010, 35, 211-218. [CrossRef] [PubMed]

84. Klapper, W.; Shin, T.; Mattson, M.P. Differential regulation of telomerase activity and TERT expression during brain development in mice. J. Neurosci. Res. 2001, 64, 252-260. [CrossRef]

85. Horikawa, I.; Chiang, Y.J.; Patterson, T.; Feigenbaum, L.; Leem, S.-H.; Michishita, E.; Larionov, V.; Hodes, R.J.; Barrett, J.C. Differential cis-regulation of human versus mouse TERT gene expression in vivo: Identification of a human-specific repressive element. Proc. Natl. Acad. Sci. USA 2005, 102, 18437-18442. [CrossRef]

86. Kota, L.N.; Bharath, S.; Purushottam, M.; Moily, N.S.; Sivakumar, P.T.; Varghese, M.; Pal, P.K.; Jain, S. Reduced telomere length in neurodegenerative disorders may suggest shared biology. J. Neuropsychiatry Clin. Neurosci. 2015, 27, e92-6. [CrossRef]

87. Holohan, B.; Wright, W.E.; Shay, J.W. Telomeropathies: An emerging spectrum disorder. J. Cell Biol. 2014, 205, 289-299. [CrossRef] [PubMed] 
88. Alsiary, R.; Brownhill, S.C.; Brüning-Richardson, A.; Hutson, R.; Griffin, N.; Morrison, E.E.; Bond, J.; Burchill, S.A.; Bell, S.M. Expression analysis of the MCPH1/BRIT1 and BRCA1 tumor suppressor genes and telomerase splice variants in epithelial ovarian cancer. Gene 2018, 672, 34-44. [CrossRef] [PubMed]

89. Nguyen, K.T.T.T.; Wong, J.M.Y. Telomerase Biogenesis and Activities from the Perspective of Its Direct Interacting Partners. Cancers 2020, 12, 1679. [CrossRef]

90. Choi, J.; Southworth, L.K.; Sarin, K.Y.; Venteicher, A.S.; Ma, W.; Chang, W.; Cheung, P.; Jun, S.; Artandi, M.K.; Shah, N.; et al. TERT promotes epithelial proliferation through transcriptional control of a Myc- and Wnt-related developmental program. PLoS Genet. 2008, 4, e10. [CrossRef]

91. Zhang, Y.; Toh, L.; Lau, P.; Wang, X. Human telomerase reverse transcriptase (hTERT) is a novel target of the Wnt/ $\beta$-catenin pathway in human cancer. J. Biol. Chem. 2012, 287, 32494-32511. [CrossRef]

92. Ghosh, A.; Saginc, G.; Leow, S.C.; Khattar, E.; Shin, E.M.; Yan, T.D.; Wong, M.; Zhang, Z.; Li, G.; Sung, W.-K.; et al. Telomerase directly regulates NF-кB-dependent transcription. Nat. Cell. Biol. 2012, 14, 1270-1281. [CrossRef]

93. Romaniuk, A.; Paszel-Jaworska, A.; Totoń, E.; Lisiak, N.; Hołysz, H.; Królak, A.; Grodecka-Gazdecka, S.; Rubiś, B. The noncanonical functions of telomerase: To turn off or not to turn off. Mol. Biol. Rep. 2019, 46, 1401-1411. [CrossRef]

94. Liu, N.; Ding, D.; Hao, W.; Yang, F.; Wu, X.; Wang, M.; Xu, X.; Ju, Z.; Liu, J.-P.; Song, Z.; et al. hTERT promotes tumor angiogenesis by activating VEGF via interactions with the Sp1 transcription factor. Nucleic Acids Res. 2016, 44, 8693-8703. [CrossRef]

95. Qin, Y.; Tang, B.; Hu, C.J.; Xiao, Y.F.; Xie, R.; Yong, X.; Wu, Y.Y.; Dong, H.; Yang, S.M. An HTERT/ZEB1 Complex Directly Regulates E-Cadherin to Promote Epithelial-to-Mesenchymal Transition (EMT) in Colorectal Cancer. Oncotarget 2016, 7, 351-361. [CrossRef] [PubMed]

96. Smith, L.L.; Coller, H.A.; Roberts, J.M. Telomerase modulates expression of growth-controlling genes and enhances cell proliferation. Nat. Cell. Biol. 2003, 5, 474-479. [CrossRef] [PubMed]

97. Haendeler, J.; Dröse, S.; Büchner, N.; Jakob, S.; Altschmied, J.; Goy, C.; Spyridopoulos, I.; Zeiher, A.M.; Brandt, U.; Dimmeler, S. Mitochondrial telomerase reverse transcriptase binds to and protects mitochondrial DNA and function from damage. Arter. Thromb. Vasc. Biol. 2009, 29, 929-935. [CrossRef] [PubMed]

98. Gordon, D.M.; Santos, J.H. The emerging role of telomerase reverse transcriptase in mitochondrial DNA metabolism. J. Nucleic Acids 2010, 2010, 390791. [CrossRef] [PubMed]

99. Salvadores, M.; Fuster-Tormo, F.; Supek, F. Matching cell lines with cancer type and subtype of origin via mutational, epigenomic, and transcriptomic patterns. Sci. Adv. 2020, 6, eaba1862. [CrossRef] [PubMed]

100. Dahlin, A.M.; Wibom, C.; Ghasimi, S.; Brännström, T.; Andersson, U.; Melin, B. Relation between Established Glioma Risk Variants and DNA Methylation in the Tumor. PLoS ONE 2016, 11, e0163067. [CrossRef] [PubMed]

101. Wheeler, D.L.; Church, D.M.; Federhen, S.; Lash, A.E.; Madden, T.L.; Pontius, J.U.; Schuler, G.D.; Schriml, L.M.; Sequeira, E.; Tatusova, T.A.; et al. Database resources of the National Center for Biotechnology. Nucleic Acids Res. 2003, 31, 28-33. [CrossRef]

102. Nicholson, P.; Yepiskoposyan, H.; Metze, S.; Zamudio Orozco, R.; Kleinschmidt, N.; Mühlemann, O. Nonsense-mediated mRNA decay in human cells: Mechanistic insights, functions beyond quality control and the double-life of NMD factors. Cell. Mol. Life Sci. 2010, 67, 677-700. [CrossRef] [PubMed]

103. Stark, R.; Grzelak, M.; Hadfield, J. RNA sequencing: The teenage years. Nat. Rev. Genet. 2019, 20, 631-656. [CrossRef]

104. Udvardi, M.K.; Czechowski, T.; Scheible, W.-R. Eleven golden rules of quantitative RT-PCR. Plant Cell 2008, $20,1736-1737$. [CrossRef]

105. Raithel, S.; Johnson, L.; Galliart, M.; Brown, S.; Shelton, J.; Herndon, N.; Bello, N.M. Inferential considerations for low-count RNA-seq transcripts: A case study on the dominant prairie grass Andropogon gerardii. BMC Genom. 2016, 17, 140. [CrossRef]

106. Weinstein, J.N.; Collisson, E.A.; Mills, G.B.; Shaw, K.R.M.; Ozenberger, B.A.; Ellrott, K.; Shmulevich, I.; Sander, C.; Stuart, J.M. The Cancer Genome Atlas Pan-Cancer analysis project. Nat. Genet. 2013, 45, 1113-1120. [CrossRef] [PubMed]

107. Gao, G.F.; Parker, J.S.; Reynolds, S.M.; Silva, T.C.; Wang, L.-B.; Zhou, W.; Akbani, R.; Bailey, M.; Balu, S.; Berman, B.P.; et al. Before and After: Comparison of Legacy and Harmonized TCGA Genomic Data Commons' Data. Cell Syst. 2019, 9, $24-34 . e 10$. [CrossRef]

108. GTEx Consortium The Genotype-Tissue Expression (GTEx) project. Nat. Genet. 2013, 45, 580-585. [CrossRef] [PubMed]

109. Battle, A.; Brown, C.D.; Engelhardt, B.E.; Montgomery, S.B. Genetic effects on gene expression across human tissues. Nature 2017, 550, 204-213. [CrossRef]

110. The Regents of the University of California, Santa Cruz All. Welcome to the Xena Functional Genomics Explorer. Available online: https:/ / xenabrowser.net (accessed on 1 May 2020).

111. Goldman, M.J.; Craft, B.; Hastie, M.; Repečka, K.; McDade, F.; Kamath, A.; Banerjee, A.; Luo, Y.; Rogers, D.; Brooks, A.N.; et al. Visualizing and interpreting cancer genomics data via the Xena platform. Nat. Biotechnol. 2020, 38, 675-678. [CrossRef]

112. Vivian, J.; Rao, A.A.; Nothaft, F.A.; Ketchum, C.; Armstrong, J.; Novak, A.; Pfeil, J.; Narkizian, J.; Deran, A.D.; Musselman-Brown, A.; et al. Toil enables reproducible, open source, big biomedical data analyses. Nat. Biotechnol. 2017, 35, 314-316. [CrossRef] [PubMed]

113. Huang, X.; Stern, D.F.; Zhao, H. Transcriptional Profiles from Paired Normal Samples Offer Complementary Information on Cancer Patient Survival-Evidence from TCGA Pan-Cancer Data. Sci. Rep. 2016, 6, 20567. [CrossRef] [PubMed]

114. Zhao, Y.; Yu, P.; Wu, R.; Ge, Y.; Wu, J.; Zhu, J.; Jia, R. Renal cell carcinoma-adjacent tissues enhance mobilization and recruitment of endothelial progenitor cells to promote the invasion of the neoplasm. Biomed. Pharm. 2013, 67, 643-649. [CrossRef] [PubMed] 
115. Jones, A.C.; Antillon, K.S.; Jenkins, S.M.; Janos, S.N.; Overton, H.N.; Shoshan, D.S.; Fischer, E.G.; Trujillo, K.A.; Bisoffi, M. Prostate field cancerization: Deregulated expression of macrophage inhibitory cytokine 1 (MIC-1) and platelet derived growth factor A (PDGF-A) in tumor adjacent tissue. PLOS ONE 2015, 10, e0119314. [CrossRef]

116. Casbas-Hernandez, P.; Sun, X.; Roman-Perez, E.; D'Arcy, M.; Sandhu, R.; Hishida, A.; McNaughton, K.K.; Yang, X.R.; Makowski, L.; Sherman, M.E.; et al. Tumor intrinsic subtype is reflected in cancer-adjacent tissue. Cancer Epidemiol. Biomark. Prev. A Publ. Am. Assoc. Cancer Res. Cosponsored Am. Soc. Prev. Oncol. 2015, 24, 406-414. [CrossRef]

117. Suntsova, M.; Gaifullin, N.; Allina, D.; Reshetun, A.; Li, X.; Mendeleeva, L.; Surin, V.; Sergeeva, A.; Spirin, P.; Prassolov, V.; et al. Atlas of RNA sequencing profiles for normal human tissues. Sci. Data 2019, 6, 36. [CrossRef]

118. The Broad Institute of MIT \& Harvard. CCLE Cancer Cell Line Encyclopedia. Available online: https://portals.broadinstitute. org/ccle (accessed on 1 May 2020).

119. Ding, Z.; Mangino, M.; Aviv, A.; Spector, T.; Durbin, R. Estimating telomere length from whole genome sequence data. Nucleic Acids Res. 2014, 42, e75. [CrossRef]

120. McInnes, L.; Healy, J.; Saul, N.; Großberger, L. UMAP: Uniform Manifold Approximation and Projection. J. Open Source Softw. 2018, 3, 861. [CrossRef]

121. National Cancer Institute at the National Institutes of Health. TCGA Ethics \& Policies. Available online: https://www.cancer. gov/about-nci/organization/ccg/research/structural-genomics/tcga/history/policies (accessed on 1 May 2020).

122. National Cancer Institute, Biorepositories \& Biospecimen Research Branch. Genotype-Tissue Expression (GTEx) Project. Available online: https:/ / biospecimens.cancer.gov/resources/sops/gtex.asp (accessed on 1 May 2020). 